\title{
Angola: Fourth Review Under the Stand-By Arrangement, Request for Waivers of Nonobservance of Performance Criteria, Request for Waivers of Applicability of Performance Criteria, and Request for Modification of Performance Criteria.
}

The following documents have been released and are included in this package:

- $\quad$ The staff report, prepared by a staff team of the IMF, following discussions that ended on November 10, 2010, with the officials of Angola on economic developments and policies. Based on information available at the time of these discussions, the staff report was completed on January 11, 2011. The views expressed in the staff report are those of the staff team and do not necessarily reflect the views of the Executive Board of the IMF.

- $\quad$ A supplement to the staff report;

- $\quad$ A staff statement;

- A press release;

- A statement by the Executive Director for Angola.

The document(s) listed below will be separately released:

- $\quad$ Letter of Intent sent to the IMF by the authorities of Angola*

- Memorandum of Economic and Financial Policies*

- $\quad$ Technical Memorandum of Understanding*

*Also included in staff report.

The policy of publication of staff reports and other documents allows for the deletion of market-sensitive information.

\author{
Copies of this report are available to the public from \\ International Monetary Fund • Publication Services \\ $70019^{\text {th }}$ Street, N.W. $\bullet$ Washington, D.C. 20431 \\ Telephone: (202) 623-7430 • Telefax: (202) 623-7201 \\ E-mail: publications@imf.org Internet: http://www.imf.org
}

\section{International Monetary Fund Washington, D.C.}


INTERNATIONAL MONETARY FUND

\title{
ANGOLA \\ Fourth Review Under the Stand-By Arrangement, Request for Waivers of Nonobservance of Performance Criteria, Request for Waivers of Applicability of Performance Criteria, and Request for Modification of Performance Criteria ${ }^{1}$
}

\author{
Prepared by the African Department \\ (In Consultation with Other Departments)
}

Approved by Saul Lizondo and Dhaneshwar Ghura

January 10, 2011

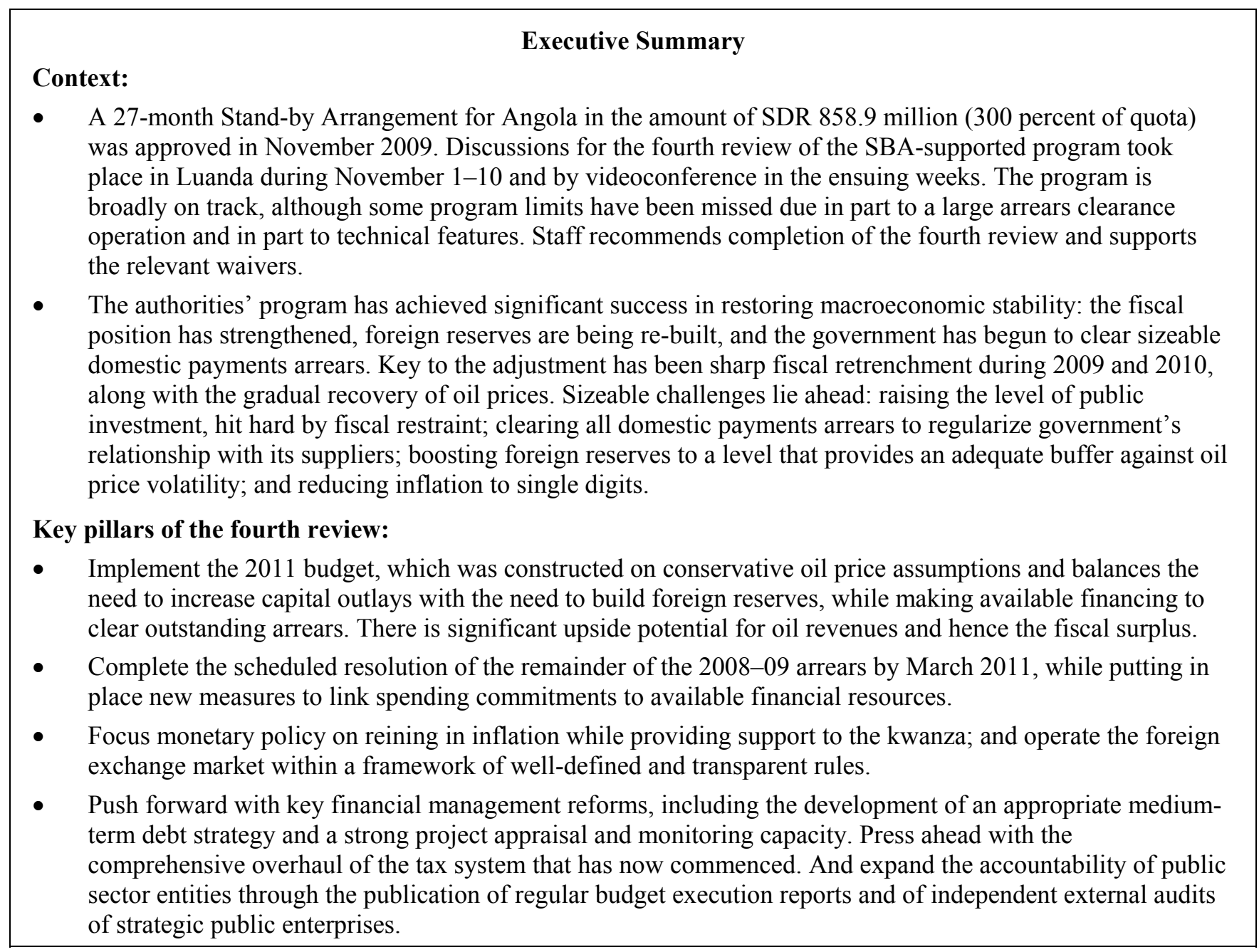

1 A staff team consisting of Messrs. Nolan (head), Cuevas, Al-Hassan, and Xiao, and Ms. Yackovlev (all AFR) and Ms. Richmond (FAD) visited Luanda during November 1-11, 2010. The team held discussions with the Minister of Planning, the Minister of Finance, the Governor of the Central Bank, other senior government officials, and financial market and private sector participants. 


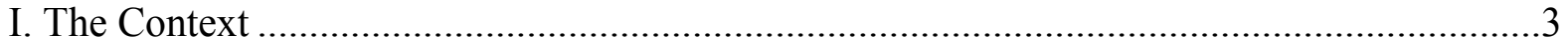

II. Recent Developments and Outlook....................................................................

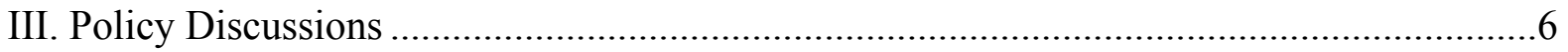

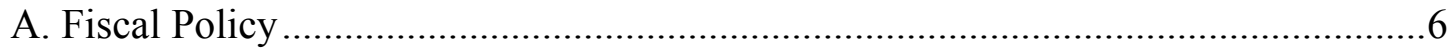

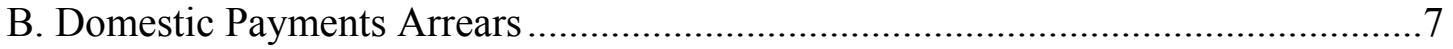

C. Monetary, Exchange Rate, and Financial Sector Policies.....................................

D. The Administrative and Policy Reform Agenda.................................................

IV. Program Monitoring and Design Issues ................................................................ 10

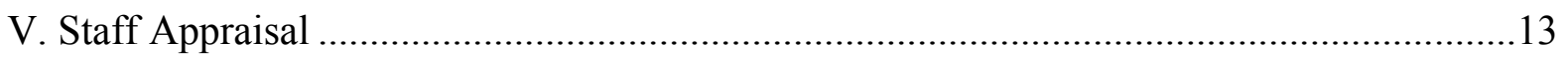

Tables

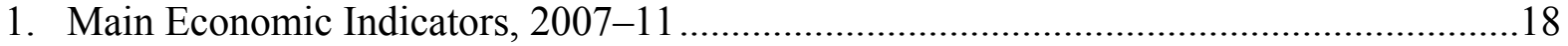

2a. Fiscal Operations of the Central Government, 2008-11 .................................................19

2b. Fiscal Operations of the Central Government, 2008-11 .............................................20

2c. Fiscal Operations of the Central Government, 2009-11 …........................................21

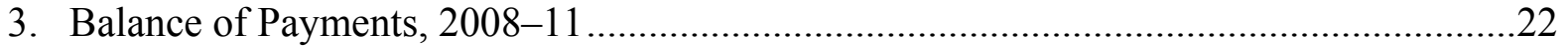

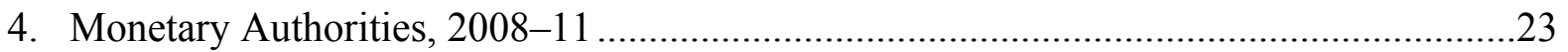

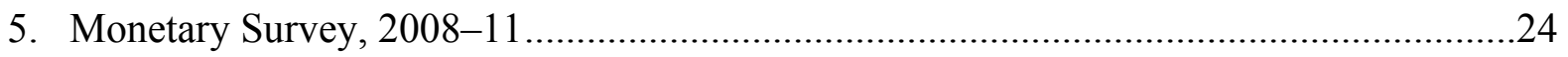

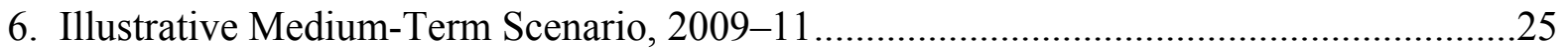

7. Banking System Financial Soundness Indicators, 2003-10 .......................................26

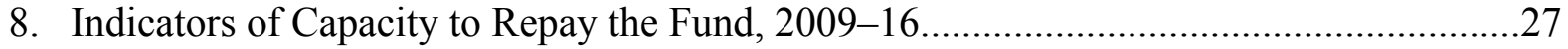

9. Reviews and Disbursements Under the 27-Month Stand-By-Arrangment......................28

Figures

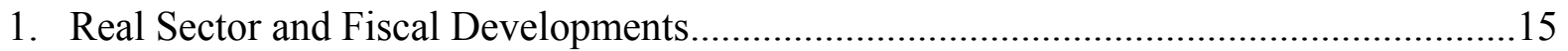

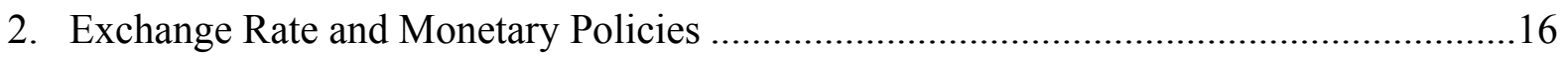

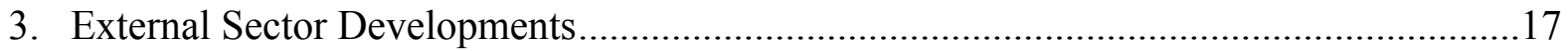

Appendices

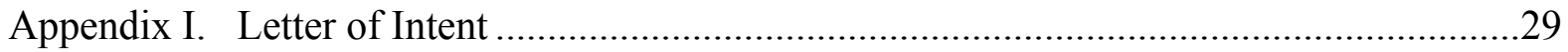

Attachment I. Memorandum of Economic and Financial Policies .....................................32

Attachment II. Technical Memorandum of Understanding ............................................41

Annexes

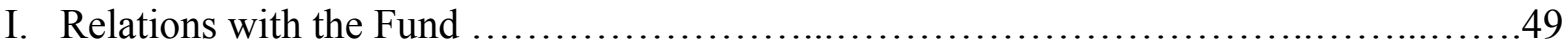

II. Relations with the World Bank ................................................51

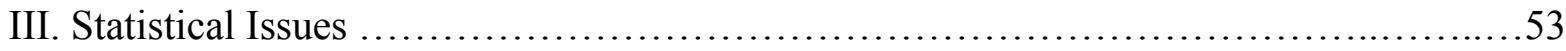




\section{The ConteXT}

1. The Angolan economy was badly buffeted by the sharp drop in global oil prices that began in late-2008. Oil is central to the Angolan economy, contributing 75 percent of government revenues and 96 percent of merchandise exports, and the erosion of oil revenues destabilized both the public finances and the balance of payments. The budget moved into a sizeable deficit; interest rates rose sharply; and the exchange rate, defended by a mix of a reserve depletion and rationing of foreign exchange, came under severe pressure. Facing sizeable financing needs, the authorities began to default on payment obligations to domestic suppliers, undermining the financial position of these entities.

\section{The authorities initiated a comprehensive adjustment program in late-2009,} supported by a Stand-By Arrangement (SBA) with the Fund. Key measures taken included: a sharp fiscal adjustment, focused on expenditure reduction; ${ }^{2}$ reform of the foreign exchange auction system, which led to significant depreciation of the kwanza; maintenance of a tight monetary policy to support the exchange rate; intensified monitoring of commercial banks to safeguard financial sector stability; and a substantial package of reform measures, focused on improving public financial management and the internal governance of the central bank.

3. The authorities' program has achieved significant success, helped in part by some recovery in oil prices, but also by solid implementation of key program measures. The nonoil primary deficit (NOPD), a key fiscal indicator, was cut sharply in 2009 and again in 2010; monetary policy provided support for the exchange rate, while reserves were being rebuilt; the commercial banks appear to have weathered the storm, albeit with some damage to the quality of loan portfolios; and significant reform measures have been completed or set in motion.

\begin{tabular}{|c|c|c|c|c|c|}
\hline \multicolumn{6}{|c|}{ Text Table 1. Angola: Key Economic Indicators, 2008-11 } \\
\hline & \multirow[t]{2}{*}{2008} & \multirow[t]{2}{*}{2009} & \multicolumn{2}{|l|}{2010} & \multirow{2}{*}{$\begin{array}{r}2011 \\
\text { Proj. }\end{array}$} \\
\hline & & & EBS/09/171 & Proj. & \\
\hline Real non-oil GDP (percent change) & 15.0 & 8.1 & 7.7 & 4.7 & 8.1 \\
\hline CPI (percent change, end of period) & 13.2 & 14.0 & 13.0 & 15.0 & 10.8 \\
\hline Fiscal balance (percent of GDP) & 8.8 & -8.6 & 1.5 & 7.5 & 4.5 \\
\hline Non-oil primary fiscal balance (percent of non-oil GDP) & -70.9 & -46.6 & -46.8 & -39.5 & -40.2 \\
\hline Net international reserves (millions of U.S. dollars) & 15,378 & 10,251 & 11,040 & 13,668 & 14,914 \\
\hline Gross reserves import cover ${ }^{1}$ & 5.1 & 3.9 & 4.2 & 4.3 & 4.3 \\
\hline
\end{tabular}

\section{But important challenges need to be addressed to complete the stabilization}

process. The large stock of government payment arrears accumulated in 2008-09 needs to be settled. Public investment, cut sharply since 2008, needs to be raised to address the country's

\footnotetext{
${ }^{2}$ The fiscal adjustment had commenced earlier in the year, as part of the government's initial response to the collapse of budgetary revenues.
} 
major infrastructure deficiencies. Reserves remain below pre-crisis levels and further accumulation is needed to provide a solid buffer against oil price volatility. Inflation, drifting upwards in response to oil price adjustments, needs to be reined in. And the government's longer-term reform program needs to be pushed forward.

\section{RECENT DEVELOPMENTS AND OUTLOOK}

\section{Macroeconomic performance during 2010 has been mixed, partly reflecting the} effects of the sizeable adjustment measures taken:

- $\quad$ GDP is expected to rise by some 2.3 percent in 2010, a combination of a 1.3 percent drop in oil production (hit by temporary production difficulties) and a projected 4.7 percent increase in non-oil GDP, a very sluggish pace relative to pre-crisis trends. Contributory factors to slowing non-oil growth included the contractionary impact of fiscal adjustment and the burden of government payments arrears on local firms.

- $\quad$ Inflation has risen slightly in recent months, following a 50 percent increase in gasoline prices in September 2010. Twelve-month inflation reached 16.1 percent in October, up from 13.5 percent a year previously — a modest increase given the fuel price adjustments and the sizeable currency depreciation in the final quarter of 2009.

- $\quad$ The budget has moved into surplus, with the full-year surplus likely to be on the order of $71 / 2$ percent of GDP. Expenditures have been running well below (revised) budgeted levels due to slow execution of capital expenditures, but staff expects some pick-up in recorded outlays late in the year. While stronger-than-programmed oil receipts have contributed importantly to the improved budgetary position, the non-oil primary deficit looks set to have declined by some 7 percentage points of non-oil GDP from its 2009 level, underscoring the scale of domestic fiscal adjustment.

- $\quad$ The strengthening of the fiscal position provided space for the clearance of some of the arrears accumulated in 2008-09. Having initiated a process of verification of these arrears, the authorities had, by end-year, cleared some 50 percent of the initial stock of verified arrears (about US\$3.6 billion out of US\$6.8 billion, including all arrears to "small" suppliers).

- $\quad$ The exchange rate has been broadly stable over the course of 2010, fluctuating within a range of $\mathrm{Kz} 90$ to $93.5 \mathrm{per}$ U.S. dollar. The authorities continue to closely manage the exchange rate, but have moved to improve the workings of the foreign exchange auction, including by standardizing the timing and length of the auction window. The parallel market premium is running at around 5 percent.

- $\quad$ Foreign reserves are being rebuilt, with gross international reserves set to increase by at least US\$3 billion over the full year; the expected improvement in the import coverage ratio is more modest, partly reflecting fluctuations in import levels. 
- $\quad$ Broad money growth has been kept in check, with the 23 percent expansion now anticipated for 2010 being slightly lower than original program targets, ${ }^{3}$ private credit growth has been slightly higher than originally programmed. With restoration of confidence, short-term interest rates have eased significantly in recent months without generating renewed exchange rate pressures.

- $\quad$ Three end-September quantitative performance criteria - on the accumulation of new domestic payments arrears, central bank net domestic credit, and net credit to government extended by the banking system-were missed. The causes are discussed below ( $(24)$.

6. The external environment for Angola in 2011 appears broadly favorable, with oil prices expected to increase on 2010 levels, but the global economic outlook is characterized by significant uncertainty. The policy framework agreed with the authorities takes a conservative stance on oil prices, setting the oil price some US\$5 per barrel below the October WEO projections, adjusted for the modest quality discount on Angolan oil. ${ }^{4}$ The agreed fiscal framework effectively locks in the sizeable fiscal consolidation achieved in 2010, with the non-oil primary deficit increasing only marginally relative to non-oil GDP. While there is likely to be little direct demand stimulus from budgetary policies, the return of more stable macroeconomic conditions and the settlement of remaining government payments arrears should provide a solid boost to the non-oil sector:

- $\quad G D P$ is projected to rise by some $6 \frac{1}{2}$ percent in 2011 , with oil sector growth (from temporarily deflated levels in 2010) amounting to 3.8 percent and non-oil sector activity set to rise by some 8.1 percent - much closer to trend growth rates.

- Inflation is expected to decline gradually in 2011, reflecting continued tight control of monetary growth and the eventual dropping out of the large 2010 fuel price increases from the index.

- $\quad$ The balance of payments position is projected to provide room for reserve accumulation on the order of US\$1.7 billion -with significant upside potential if October WEO oil price projections are realized or exceeded.

\footnotetext{
${ }^{3}$ Constructed on constant exchange rates (as was the case in the original projections), the projected M2 growth rate for 2010 would be 20 percent.

${ }^{4}$ With oil prices US\$5 per barrel higher than programmed (i.e. at October WEO levels), reserve accumulation in 2011 would be some US\$1.7 billion higher than programmed here, with the fiscal surplus increasing by some 2 percent of GDP. A realized 2011 oil price of US\$10 above the program level would have a commensurately larger impact on reserves and the fiscal position.
} 
- $\quad$ Given the conservative oil price assumptions, the risks to the macroeconomic framework have an upside bias. The macroeconomic framework may need to be adjusted in due course if a large oil revenue windfall materializes.

\section{Policy Discussions}

7. Policy discussions for the review focused on: a) the 2011 budget; b) the handling of the arrears problem; c) monetary and exchange rate policies; and d) key elements of the authorities' administrative and policy reform agenda.

\section{A. Fiscal Policy}

8. Both the authorities and staff favored the adoption of a conservative oil price assumption in setting budgetary policy. With the authorities committed both to further accumulation of foreign reserves and to reversing the sharp squeeze on public sector investment in 2009-10, there was active discussion of the quantitative trade-offs involved in pursuing each objective, along with dialogue on the scope for creating fiscal space through measures elsewhere in the budget.

\begin{tabular}{|c|c|c|c|c|}
\hline \multicolumn{5}{|c|}{$\begin{array}{l}\text { Text Table 2. Angola: Budget Developments, 2008-11 } \\
\text { (Percent of non-oil GDP) }\end{array}$} \\
\hline & 2008 & 2009 & 2010 & 2011 \\
\hline & & & Proj. & Proj. \\
\hline Current expenditure ${ }^{1}$ & 64.1 & 48.7 & 48.6 & 44.8 \\
\hline Capital expenditure & 32.5 & 22.3 & 14.9 & 16.8 \\
\hline Non-oil primary fiscal balance & -70.9 & -46.6 & -39.5 & -40.2 \\
\hline
\end{tabular}

- $\quad$ Staff called for a more gradual build-up in public investment than proposed by the authorities, citing the adverse impact of additional domestically-financed investment on imports and reserve accumulation; the authorities underscored the need to push ahead with small-scale investment programs in the provinces that would have high economic payoffs. The final agreement was that the 2011 budget would adopt a cautious stance, largely following the staff proposal; but that this position could be revisited in mid-year if oil prices evolved more favorably than assumed. ${ }^{5}$

- $\quad$ Staff pressed the case for a further reduction in fuel subsidies during 2011, arguing that the distributional impact of the subsidies was quite regressive. The authorities

\footnotetext{
${ }^{5}$ As structured, the adjustors on the fiscal and reserve targets imply that oil windfalls should be reflected in higher reserve accumulation rather than spending. The case for modifying budgetary plans to increase investment outlays, should there be a sizeable oil windfall, will be discussed as part of the $5^{\text {th }}$ program review.
} 
accepted this point, but emphasized that there would be strong public resistance to another large fuel price increase after the price adjustments in September 2010.

- Staff inquired as to the scope for raising non-oil revenues to generate fiscal space for higher investment. The authorities noted that they were undertaking a major overhaul of the tax system that would boost non-oil revenues over the medium term, but the reforms would take time and had only recently been set in motion. The political leadership has recently ordered an intensification of tax enforcement in Luanda to reduce tax evasion; officials expected significant revenue gains from these efforts, but deemed it premature to build revenue gains into the 2011 budget.

9. The authorities and staff agreed on the merits of adopting some form of fiscal rule (or principle) that would ensure smoothing of expenditure over the oil price cycle, while providing for a gradual build-up of resources in some form of sovereign wealth or stabilization fund. The authorities were unconvinced of the case for anchoring fiscal policy around a rule that smoothed inter-temporal consumption from oil wealth (e.g. setting a target for the non-oil primary deficit), arguing that investing today in infrastructure and other growth-supporting projects would provide greater benefits for future generations than saving surpluses. That said, they saw solid merit in following some form of structural balance rule that would smooth spending levels over the oil price cycle, and asked staff to prepare a detailed proposal for discussion by the time of the Article IV Consultation and $5^{\text {th }}$ review.

\section{B. Domestic Payments Arrears}

10. The government's arrears clearance program is well underway. As a first step, the government during the third quarter made cash payments to clear some US $\$ 2.7$ billion (including all "small" claims) of the US\$6.8 billion in 2008-09 payments arrears that had been verified; a further US\$0.9 billion was cleared through cash payments late in the fourth quarter. During November, broad understandings were reached with the holders of the remaining claims (with details to be finalized in January), committing the government to clear the remaining arrears in the first quarter of 2011, via a mix of cash and securitizations. ${ }^{6}$

\section{The quantitative performance criterion on the non-accumulation of domestic} payments arrears was not met as of end-September. There was a build-up of accounts payable linked to the 2010 budget of some US\$1.2 billion through end-September, with the increment during Q3 amounting to some US\$230 million. ${ }^{7}$ The authorities noted that accumulation of accounts payable over the course of the year is not abnormal: budgetary law

\footnotetext{
${ }^{6}$ The final stock of verified arrears from 2008-09 will increase from the initial estimate of US\$6.8 billion as the verification process moves to completion. The authorities intend to clear all verified arrears from $2008-09$ by end-March 2011 (structural benchmark).

${ }^{7}$ The build-up of accounts payable did not reflect financial stress: over the period, the government paid down its stock of domestic debt by some US\$2.6 billion, in addition to the US\$2.7 billion clearance of 2008-09 arrears.
} 
specifies that such amounts are deemed to be in arrears only after the budget year has closed. The authorities cleared the bulk of the stock of payables accumulated through endSeptember 2010 by January 7, 2011, with the remainder to be cleared in the coming weeks. Payables accumulated during the final quarter of the year are to be cleared by end-March 2011 (as is allowed under budget law).

12. The authorities informed staff that information on the stock of accounts payable accumulated during the first half of the year reported at the time of the $2^{\text {nd }}$ and $3^{\text {rd }}$ reviews was inaccurate, in large part because it erroneously included accounts payable relating to a state enterprise. The stock of payables accumulated during the first semester amounted to $\mathrm{Kz} 89$ billion (some US\$1 billion), rather than the $\mathrm{Kz} 165$ billion (US $\$ 1.8$ billion) previously reported.

13. The authorities are confident that the legislative and regulatory changes introduced during the third quarter of 2010 will ensure that the incurring of new spending commitments will remain under the tight control of the Ministry of Finance. The key measure taken has been the introduction of quarterly financial plans for line ministries that constrains outlays by each ministry to a ceiling agreed in advance with the Ministry of Finance: the line ministry can enter into new payment commitments only if there is space in its financial plan. These quarterly plans constrain initiation of budget-approved projects when finances are tight (and hence override the authorization provided in the budget law).

\section{Monetary, Exchange Rate, and Financial Sector Policies}

14. The pace of growth of broad money is somewhat below program expectations. The expansion of the monetary base has been significantly below program targets, reflecting active sterilization operations by the BNA, which doubled the issued stock of central bank bills during the first nine months of 2010. The sale of BNA bills required was magnified by the Treasury's decision to pay off its short-term debt over the same period. The authorities agreed that the burden on the BNA needed to be reduced, and have since resumed T-bill sales in November both to finance upcoming treasury outlays and to allow the BNA run down its outstanding stock of paper (MEFP ๆ12).

\section{Staff and the authorities agreed on a monetary program for 2011, framed around} the objectives of gradually reducing inflation while meeting the program objective of achieving an increase in gross international reserves of US\$1.7 billion. The working assessment is that monetary growth on the order of 22 percent is aligned with these objectives, and targets on BNA net domestic credit are set accordingly. Given uncertainties around the scope for financial deepening in 2011, it was agreed that the program would be constructed on conservative assumptions and could be revisited in mid-year (MEFP $\$ 10$ ).

16. The BNA views maintenance of broad exchange rate stability as a key support for market confidence and financial sector stability, while also recognizing the need for adjustment of the value of the kwanza should there be a significant shift in market fundamentals. The BNA has moved to improve the workings of the foreign exchange 
auction, by standardizing the timing for conducting the auction and improving its capacity to forecast auction demand, and will continue to use its outlier policy sparingly (MEFP $\llbracket 11){ }^{8}$

17. Angolan banks have not been severely impaired by the financial instability of the past two years and the sector maintains an adequate capital buffer. But nonperforming loans (NPLs) have been rising during 2010 from 2.6 percent at end-2009 to 7.1 percent by end-September 2010, in part reflecting the liquidity difficulties of companies affected by government payment arrears. Settlement of these payments arrears should, indirectly, help improve the NPL situation, but the evolution of NPLs will need to be kept under close review. New prudential measures to contain risks to the banking system are described in MEFP $\$ 14$. The planned FSAP, set to begin in March, provides the opportunity to undertake a comprehensive assessment of the financial system.

\section{The Administrative and Policy Reform Agenda}

18. Discussions on the authorities' reform agenda focused on four elements: a) public financial management; b) tax reform; c) improving the business environment; and d) transparency and safeguards issues.

19. On public financial management: The debt management unit is being staffed, and it is expected that a debt management strategy will be finalized, with assistance from a resident advisor, by end-March 2011. The AfDB-assisted project to strengthen project appraisal capacity and monitoring has not yet been approved by the AfDB Board; the authorities expect it to be underway by the beginning of February 2011 and delivering usable analysis and input to the 2012 budget formulation process. Legislation to establish a framework for public-private partnerships is to be passed in the coming months, and internal capacity to manage such engagements is being built. The authorities are also developing a new framework for enhancing oversight of public enterprises, with draft legislation to be submitted to the National Assembly by end-March 2011 (MEFP q17).

20. On tax reform: The authorities have commenced a multi-year overhaul of the tax system (both policies and administration). Draft legislation modernizing the legal framework is with the National Assembly. An international management consultancy has been engaged to help design a reform program and a road-map for implementation; a time-bound action plan is to be submitted to the cabinet by end-June 2011 (MEFP $\$ 18$ ).

21. On the business environment: Angola's environment for doing business is rated poorly, and the authorities recognize that substantial reforms are needed to provide the

\footnotetext{
${ }^{8}$ In the foreign exchange auction, the BNA has the right to eliminate bids it deems to be "outliers".
} 
conditions required to facilitate diversification away from over-reliance on hydrocarbons. ${ }^{9}$ The authorities explained that some reforms were underway, but underscored that dramatic change could not be achieved quickly. Staff urged the authorities to use the IFC Doing Business Report for Angola as a valuable diagnostic of weaknesses, and develop an appropriately-sequenced reform strategy on the basis of that diagnostic (MEFP $\mathbf{2 0}$ ).

22. On transparency measures: The authorities explained that the technical/capacity challenges involved in publishing quarterly reports of budget execution, including the quasifiscal operations of Sonangol on behalf of the government, had been underestimated and did not expect to meet this requirement before mid-2011; they noted that a first semester 2010 report on budget execution had been sent to the National Assembly and would be published in due course. Sonangol's 2009 audit has recently been published, as were (for the first time) the audits of a further three public enterprises. The draft legislation on oversight of public enterprises envisages all enterprises being subject to annual external audits that would be published (MEFP $¥ 17$ and 21).

23. On BNA safeguards measures: Implementation of the recommended measures has taken longer than envisaged, but the BNA has made steady progress; one outstanding action is the reconstitution of the BNA Audit Board, now expected to be completed by end-January. The BNA expects that the external audit of its 2010 financial statements will be completed by end-June 2011, and published shortly thereafter: the timeline is somewhat longer than for the 2009 audit because of the appointment of a new external auditor (MEFP |22).

\section{Program Monitoring AND Design Issues}

24. Three performance criteria were missed at end-September, in part reflecting weaknesses in the technical specification of the criteria and in part the impact of the government arrears clearance program on government finances:

- $\quad$ Regarding the domestic arrears accumulation criterion, the mechanics of the government payments and information system cannot readily track the evolution of arrears as specified in the Technical Memorandum of Understanding (TMU). ${ }^{10}$ The authorities are tracking the evolution of accounts payable (which need not be in arrears, in the sense of breaching payment conditions in specific contracts); a zero target on the quarterly accumulation of accounts payable is problematic, given the ebb and flow of government operations over the year. Staff is therefore proposing a modification of the definition of the performance criterion to cover the accumulation of accounts payable, putting a ceiling on the scale of such payables over the course of

\footnotetext{
${ }^{9}$ Angola ranks $163^{\text {rd }}$ out of 183 countries in the IFC's Doing Business Indicators 2011.

${ }^{10}$ See Country Report No. 10/302, page 48.
} 
the budget year (see the modified TMU, attached). The authorities have cleared the stock of accounts payable accumulated as of end-September (see $\$ 11$ above).

- $\quad$ Regarding the ceiling on banking system credit to government, the performance criterion at end-September was missed by some $\mathrm{Kz} 70$ billion, having been met by a modest margin at end-June. The turn-around in performance does not reflect a weak fiscal position - the NOPD is set to end the year some $\mathrm{Kz} 350$ billion below program - but rather the financing effects of the government's Kz 227 billion cash arrears clearance program during the third quarter. Arrears clearance on this scale in this quarter was not anticipated when the original financial program for the year was designed.

- $\quad$ Regarding the ceiling on net domestic credit of the BNA (NDC), there is a technical weakness in the specification of NDC in that increased open market operations to sterilize liquidity are not reflected in a contraction in NDC of the BNA. Staff proposes to rectify this defect by re-defining NDC to include (as a negative entry) the stock of BNA securities outstanding. The NDC as currently measured was Kz 160 billion above the adjusted target (pushed up in part by the large arrears clearance operation, along with the running down of the stock of government bills outstanding), but the liquidity impact of this overshooting was contained by the active sterilization operations of the BNA. Twelve-month base money growth through end-September was only 3 percent.

- $\quad$ Formal waivers for the nonobservance of end-September quantitative performance criteria are not required, given that slippage of Board consideration of the review into 2011 implies that the governing performance criteria are now those pertaining to end-December 2010. Staff considers that waiver requests, were they needed, would have been warranted, for reasons laid out above and in the authorities' letter of intent.

\section{Staff supports the waivers requested in regard to the end-December targets: ${ }^{11}$}

- Waivers are being requested for likely nonobservance of the ceilings on arrears accumulation, on central bank NDC, and on banking system credit to government.

- $\quad$ There is a significant risk that the "zero arrears accumulation" ceiling has not been observed. The authorities cleared some 60 percent of the end-September stock of accounts payable by end-December, but this decline in accounts payable could well be more than offset by the size of the normal float at end-year-which would result in nonobservance of the performance criterion. ${ }^{12}$ Staff supports the granting of a waiver on the grounds that the authorities are taking corrective actions: settling the accounts payable built up in the first three quarters of 2010 to contain the stock of accounts

\footnotetext{
${ }^{11}$ Had it been possible to bring the review to the Executive Board before end-year, staff would have proposed adjusting the end-December targets to allow for the impact of the arrears clearance operation and of the requested changes to the definitions of central bank NDC and of arrears accumulation.

${ }^{12}$ The size of the breach could be on the order of $\mathrm{Kz} 50$ billion; it is also possible that the ceiling will not be missed at all.
} 
payable; implementing the new financial control system to contain commitments by line ministries (MEFP $\mid 8$ ); and committing to clear all accounts payable deriving from the 2010 budget by end-March 2011 (as required by budget law).

- $\quad$ Staff projects that the ceiling on net credit of the banking system to the government has been missed, by a sizeable margin, perhaps by as much as $\mathrm{Kz} 180$ billion. As noted above, this is not attributable to weak fiscal performance-the NOPD is well below program targets - but rather results from unanticipated shifts in the composition of government financing; higher-than-programmed arrears clearance (which shifted government debt from the nonbank to the banking sector) and an unanticipated shortfall in non-bank financing. ${ }^{13}$ The staff supports the granting of the waiver on the grounds that the deviation was temporary, can be attributed in large part to higher-than-programmed arrears clearance (a benign development), and that above-the-line fiscal performance was much stronger than programmed; remedial measures being taken include the explicit incorporation of arrears clearance measures in the financial program, along with deeper analysis of non-bank financing to enhance forecasting and management capacity.

- $\quad$ Staff projects that the ceiling on central bank NDC at end-December has been missed by a sizeable margin, perhaps by as much as Kz 160 billion. As noted above, the ceiling is poorly defined and a revised specification is being proposed. Staff supports the waiver request on the grounds that the breach of the ceiling was temporary, and due in good part to larger-than-expected arrears clearance in 2010 (a welcome move); that the monetary impact of the nonobservance of the ceiling was fully contained by BNA operations; and that, as a remedial measure, the Ministry of Finance has substantially expanded its T-bill operations, thus containing the drawdown in government deposits (MEFP \12).

- The quantitative performance criteria on external debt contracted or guaranteed by the central government and on the non-accumulation of external arrears are continuous for the duration of the Stand-By Arrangement. Staff expects that both performance criteria have been observed and thus no waivers are requested.

- $\quad$ For the other performance criterion on the ceiling on usable net international reserves, staff supports the request for a waiver of applicability as the relevant data are not available, program performance has been strong, and there is no clear evidence this performance criterion has not been met.

\footnotetext{
${ }^{13}$ Non-bank financing is a residual and difficult to predict accurately. Also contributing to the likely nonobservance of the end-December target was the sizeable deviation between the programmed stock for end2009 and the realized outcome: this had the effect of setting the 2010 target on new bank financing of the central government at Kz-128 billion, rather than the programmed target of zero. Had it been possible to bring the review to the Executive Board before end-year, staff would have proposed adjusting the targets to allow for the unanticipated outcome at end-2009.
} 


\section{There has been a program ceiling on the contracting or guaranteeing of external} debt by the central government, set at US\$ 6 billion; this ceiling has been met to date, and is likely to be met by a margin exceeding US $\$ 4$ billion at end-year. While the authorities expect that the contracting of external loans will pick up significantly as the investment crunch comes to an end, it was agreed that the ceiling for 2011 would be reduced to US\$4 billion.

\section{Staff Appraisal}

27. Overview. Macroeconomic stabilization has been largely achieved some 14 months into the adjustment program supported by the SBA. The exchange rate has stabilized and interest rates are declining from elevated levels; foreign reserves are being steadily rebuilt; and inflation has been largely held in check. Key to these achievements has been a major fiscal adjustment during 2009-10, which saw the non-oil primary deficit cut by some 24 percentage points of non-oil GDP in 2009 and a further 7 percentage points in 2010. But the recovery process from the oil price collapse in late-2008 is still incomplete: domestic payments arrears remain to be cleared; the sharp cut in public investment outlays needs to be judiciously reversed; and inflation needs to be brought down gradually into single digits.

28. Fiscal policy. Significant expenditure restraint took place in 2010, especially in the first half of the year as the government sought to limit outlays to available financial resources - a pragmatic response to the large build-up of arrears during 2008-09. Capital spending bore the brunt of this restraint, and will now need to be gradually increased as resource availability allows. Staff welcomes the prudently-framed 2011 budget, which makes room for increased capital outlays, but regrets the fact that more fiscal space could not have been constructed by better containing current outlays, particularly the poorly-targeted fuel price subsidies. Budgetary revenues from oil have strong up-side potential: the program envisages that additional resources would go to reserve accumulation, although the spending envelope may be revisited at mid-year, when there is solid confirmation as to the strength of oil prices. Any modification to the budget at that juncture will need to avoid providing significant pro-cyclical stimulus.

29. Clearing domestic arrears. With space for arrears clearance having been made by the conjunction of spending restraint and the pick-up in oil prices, the authorities have appropriately made arrears clearance an important priority and have made a large downpayment towards clearance of the 2008-09 arrears. The authorities' intention to clear or regularize all such arrears by end-March 2011 is welcome, and should be implemented on schedule. Accounts payable arising from execution of the 2010 budget rose significantly through September; the stock will need to be kept within reasonable limits over time and be cleared within the timeframe set by the budget law.

30. Fiscal reforms. The ongoing development of the debt management unit is welcome; the unit now needs to develop a debt management strategy that can find support within the government. The delay in pressing ahead with the project monitoring and appraisal 
framework is unfortunate, but staff hopes that early approval of the African Development Bank-supported project will allow implementation to proceed soon. The multi-year overhaul of the entire (non-oil) tax system is a vital medium-term measure: the authorities need to press ahead with development of a concrete action plan, and draw on international bestpractice in fleshing out policies and institutional design.

31. Monetary and exchange rate policies. Monetary growth has remained within program targets, and it will be important that tight control on monetary expansion be maintained in 2011. With the foreign exchange market having normalized, as reflected in the narrowing of parallel market spreads towards pre-crisis levels, it will be important that the BNA manage the exchange rate using market tools - intervention operations or monetary policy adjustments - rather than rely on micro-management of the foreign exchange auction. Sparing use of the outlier policy is important if the auction market is to provide information on emerging pressures on the Kwanza.

32. Financial sector issues. Given that sizable exchange rate movements could follow a significant shift in fundamentals, the BNA is appropriately moving to tighten the regulatory environment for foreign currency lending and to further constrain bank net open positions. The upcoming FSAP provides an excellent opportunity to undertake a fundamental reassessment of the policy framework for ensuring financial sector stability, and also to identify measures to deepen the financial sector while expanding access to financial services.

33. Transparency and safeguards issues. Staff welcomes the publication of the 2009 external audits of Sonangol and three other public enterprises, along with the plan to conduct and later publish a 2010 external audit for Endiama (the state diamond producer). Delays in publishing quarterly budget reports that include quasi-fiscal operations have been attributed to capacity constraints; staff urges that these constraints be eased in a timely manner. The implementation of agreed safeguards measures, albeit delayed, represents a significant step towards strengthening internal governance at the central bank; it will be important now to move speedily toward reconstituting the BNA audit board.

34. Risks. The main risk to the authorities' program is a significant drop in world oil prices. Consistent with the authorities' practice, the budgetary framework is based on conservative oil price assumptions, providing a large buffer against an easing of oil prices from current market levels.

35. Recommendation. The Angolan authorities have achieved significant success with their stabilization efforts to date, but now need to press ahead to re-build policy buffers, to clear sizeable domestic payments arrears, and to continue their reform and modernization program. Staff recommends completion of the fourth review under the SBA and supports the granting of the requested waivers. 
Figure 1. Angola: Real Sector and Fiscal Developments

Main message: Economic growth remained slugglish in 2010 but is expected to pick up in 2011. Budget outlays declined sharply during 2009 and 2010.

GDP growth remained sluggish in 2010, due in part to a drop in construction activity.

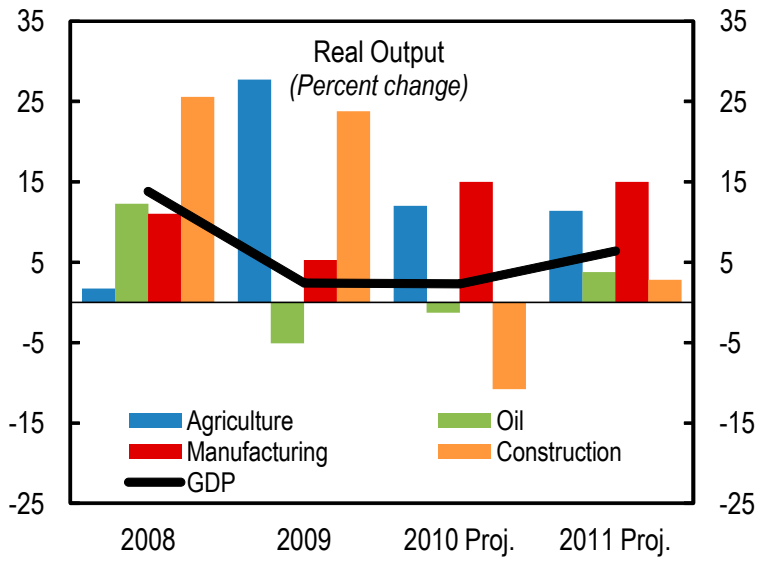

After turning into a deficit in 2009, the fiscal balance is projected to record surpluses in 2010 and 2011.

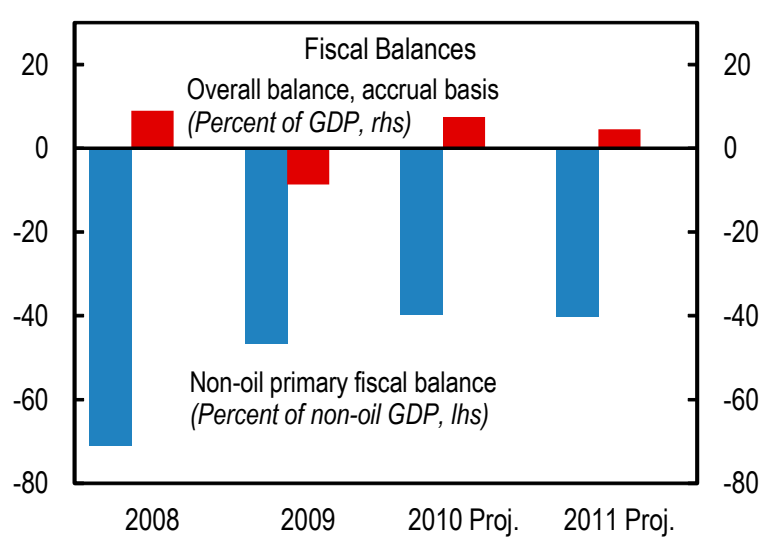

Sources: Angolan authorities and IMF staff estimates.
Inflation has been stable since mid-2009, but picked up in September 2010 following a cut in fuel subsidies.

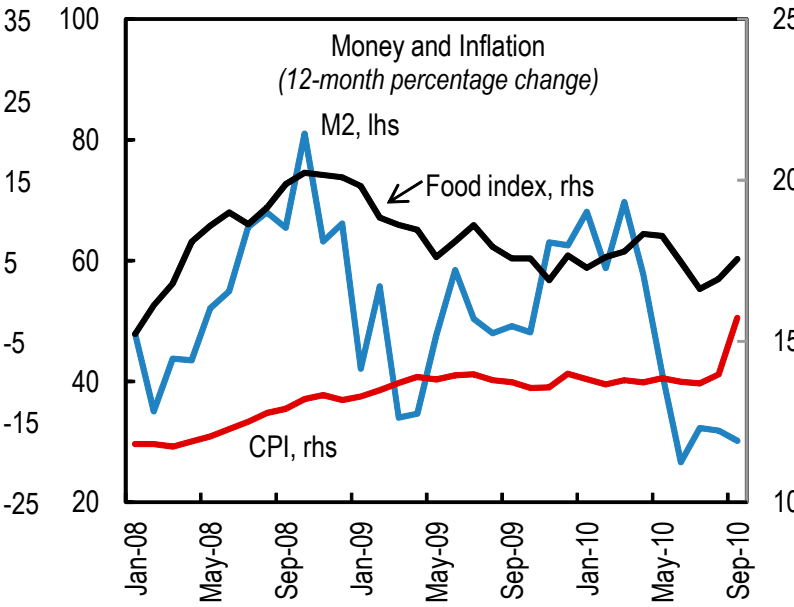

Capital spending fell sharply but is expected to pick up somewhat in 2011.

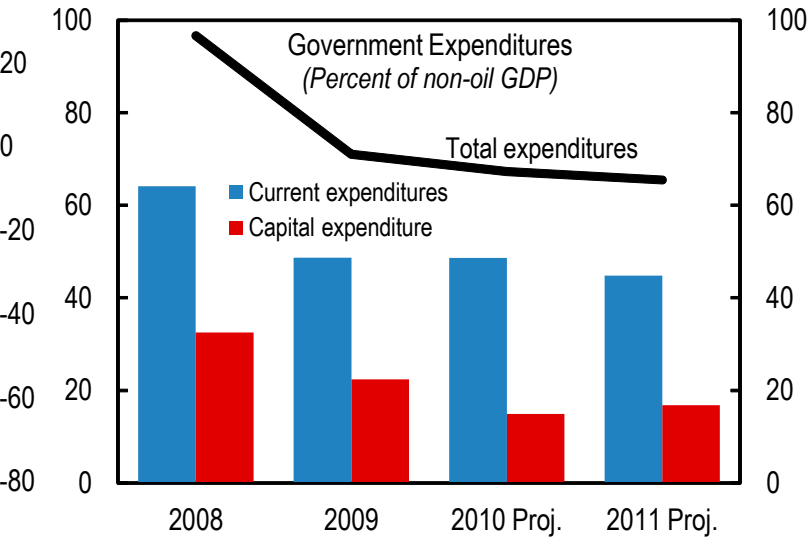


Figure 2. Angola: Exchange Rate and Monetary Policies

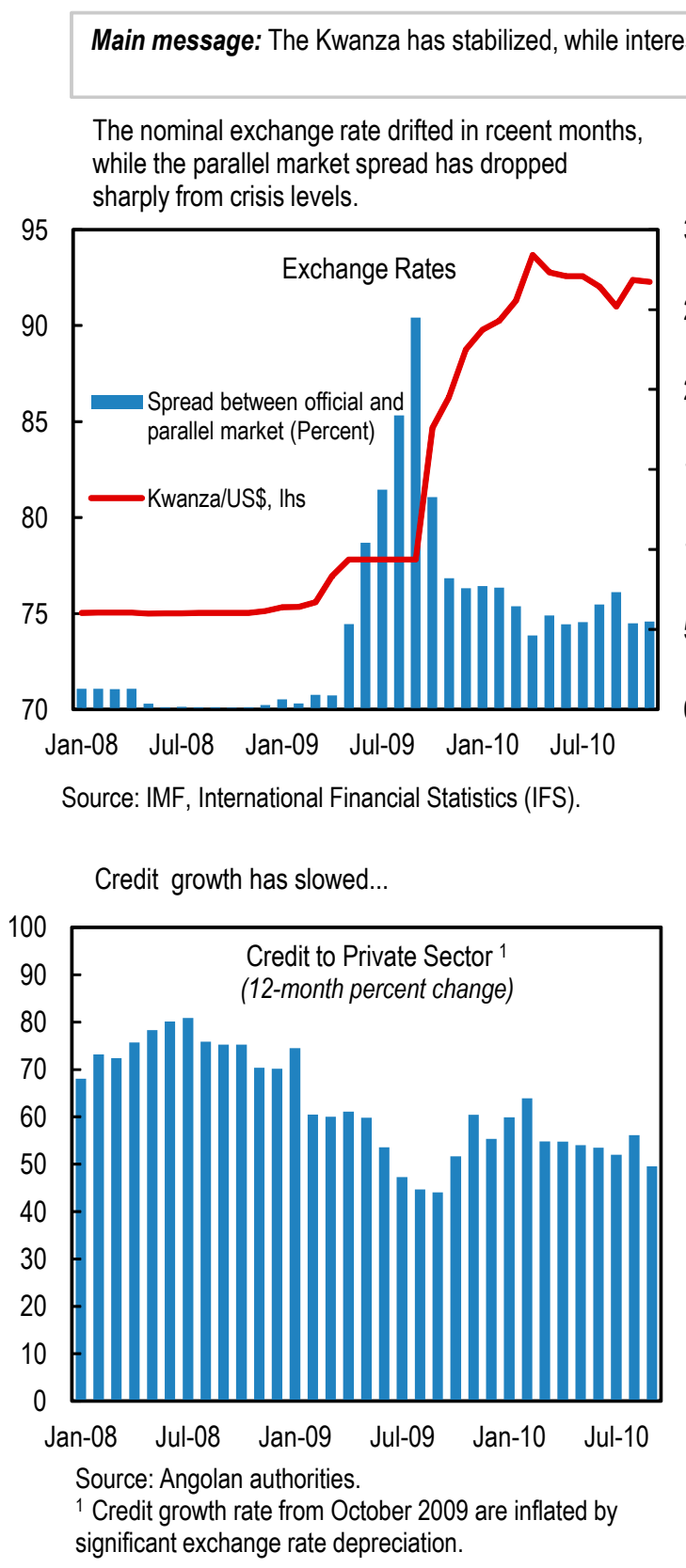

The BNA raised its policy rate during the crisis period, but has now begun to ease its stance.

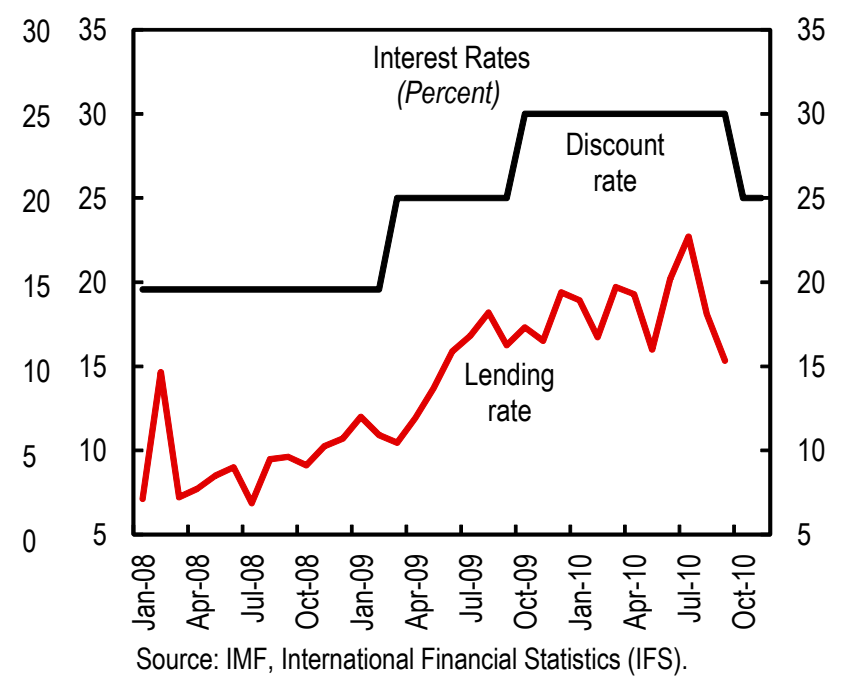

...and dollarization remains high.

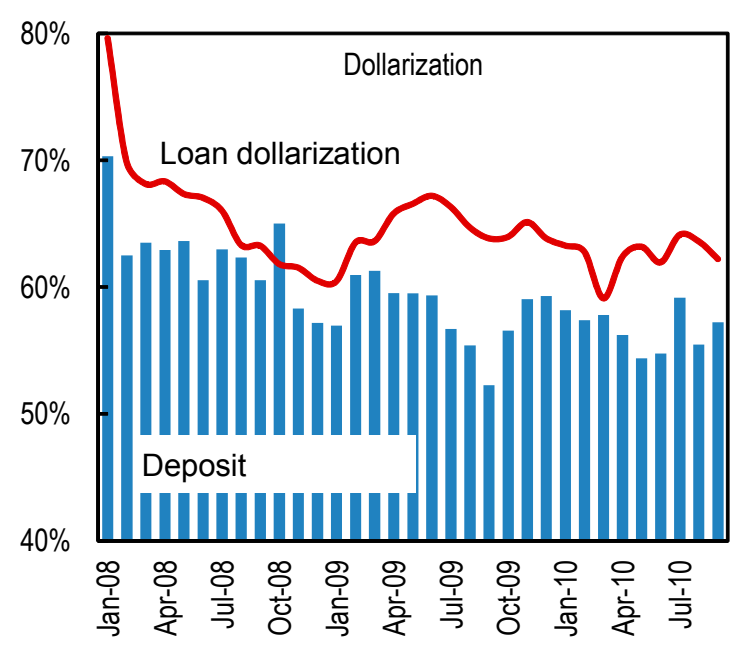

Sources: Angolan authorities and IMF staff estimates. 
Figure 3. Angola: External Sector Developments

Main message: As oil prices turn more favorable, the external position is improving and international reserves are being rebuilt.

Exports are expanding...

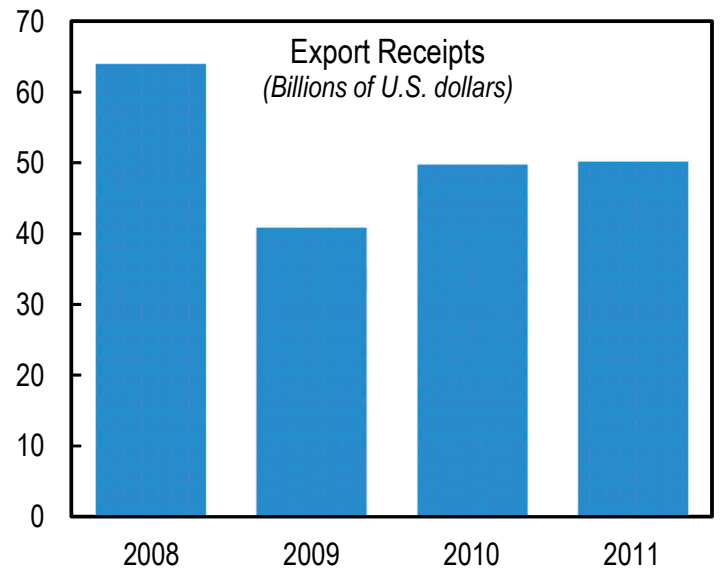

International reserves are being rebuilt...

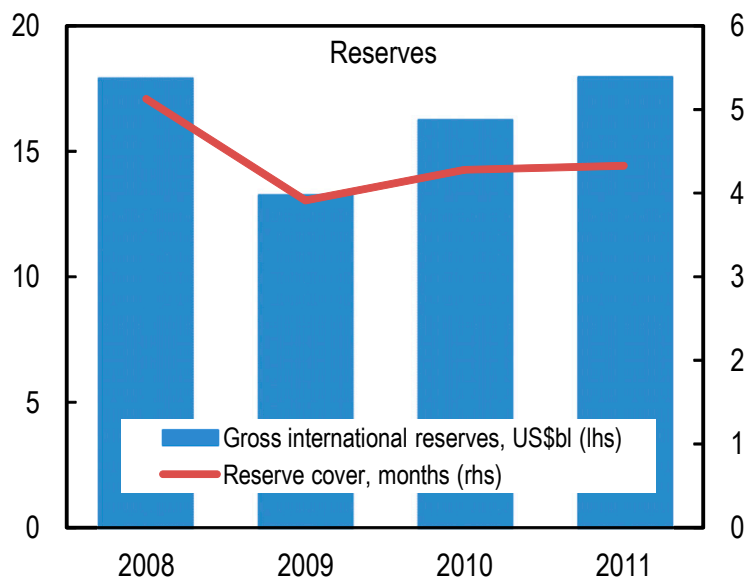

Sources: Angolan authorities and IMF staff estimates. ....and the current account has strengthened.

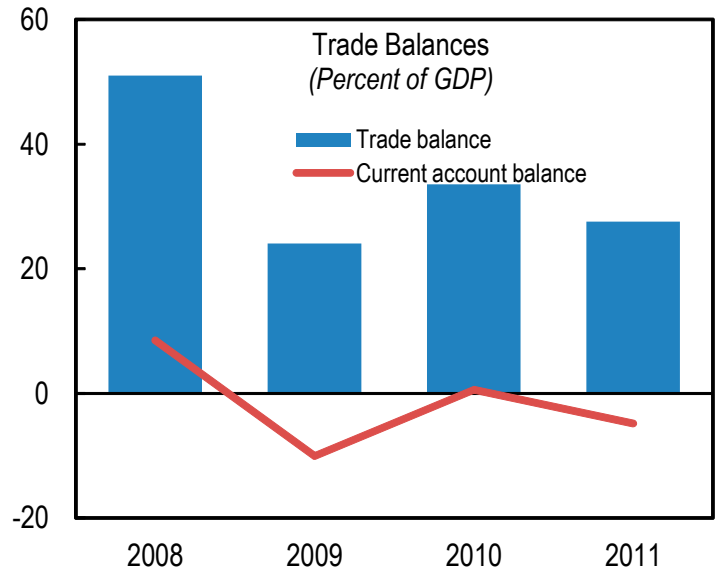

...while the real effective exchange rate appreciated

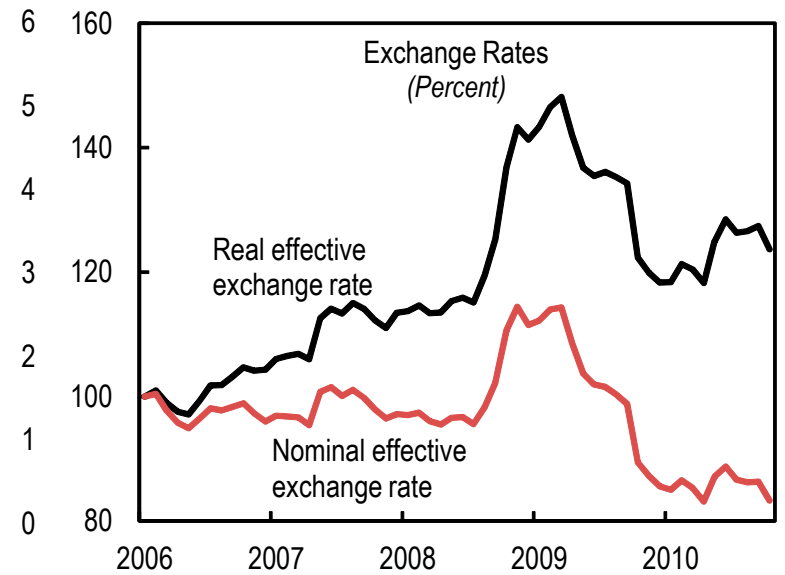


Table 1. Angola: Main Economic Indicators, 2007-11

\begin{tabular}{|c|c|c|c|c|c|}
\hline & 2007 & 2008 & 2009 & $\begin{array}{l}2010 \\
\text { Proj. }\end{array}$ & 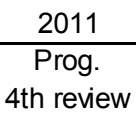 \\
\hline \multicolumn{6}{|l|}{ Real economy (percent change) } \\
\hline Real GDP & 22.6 & 13.8 & 2.4 & 2.3 & 6.4 \\
\hline Oil sector & 20.4 & 12.3 & -5.1 & -1.3 & 3.8 \\
\hline Non-oil sector & 24.4 & 15.0 & 8.1 & 4.7 & 8.1 \\
\hline Consumer price index (annual average) & 12.2 & 12.5 & 13.7 & 14.5 & 12.0 \\
\hline Consumer price index (end of period) & 11.8 & 13.2 & 14.0 & 15.0 & 10.8 \\
\hline Gross domestic product (billions of kwanzas) & 4,637 & 6,316 & 5,989 & 7,756 & 8,879 \\
\hline Of which: Non-oil gross domestic product (billions of kwanzas) & 2,100 & 2,747 & 3,327 & 3,999 & 4,834 \\
\hline Gross domestic product (millions of U.S. dollars) & 60,449 & 84,179 & 75,508 & 84,304 & 89,961 \\
\hline GDP per capita (U.S. dollars) & 3,443 & 4,671 & 4,082 & 4,425 & 4,584 \\
\hline \multicolumn{6}{|l|}{ Central government (percent of GDP) } \\
\hline Total revenues & 45.8 & 50.5 & 30.9 & 42.2 & 40.1 \\
\hline Of which: Oil & 37.1 & 40.8 & 19.4 & 31.9 & 30.3 \\
\hline Total expenditures & 34.5 & 41.6 & 39.5 & 34.7 & 35.6 \\
\hline Of which: Capital expenditures & 11.5 & 14.0 & 12.4 & 7.7 & 9.1 \\
\hline Overall balance (budget basis) & 11.3 & 8.8 & -8.6 & 7.5 & 4.5 \\
\hline Non-oil primary fiscal balance (excluding grants, budget basis) & -24.8 & -30.5 & -25.9 & -20.4 & -21.9 \\
\hline \multicolumn{6}{|l|}{ Money and credit (end-of-period, percent change) } \\
\hline Broad money & 49.3 & 93.7 & 27.5 & 22.4 & 21.0 \\
\hline Velocity (non-oil GDP/average M2) & 2.9 & 2.4 & 1.8 & 1.6 & 1.5 \\
\hline Credit to the economy (12-month percent change) & 74.2 & 70.2 & 55.4 & 26.6 & 33.4 \\
\hline \multicolumn{6}{|l|}{ Balance of payments } \\
\hline Goods and services trade balance (percent of GDP) & 30.6 & 25.1 & -0.5 & 11.6 & 5.9 \\
\hline Exports, f.o.b. (percent change, in U.S. dollars) & 39.5 & 43.8 & -36.1 & 21.8 & 0.9 \\
\hline Of which: Oil & 41.1 & 45.2 & -36.3 & 21.5 & 0.5 \\
\hline Imports, f.o.b. (percent change, in U.S. dollars) & 55.6 & 53.6 & 8.0 & -5.4 & 18.2 \\
\hline Current account balance (percent of GDP) & 15.7 & 8.5 & -10.0 & 0.6 & -4.8 \\
\hline Gross international reserves (end-of-period, millions of U.S. dollars) & 11,197 & 17,878 & 13,238 & 16,238 & 17,938 \\
\hline In months of imports of goods and services ${ }^{1}$ & 3.1 & 5.1 & 3.9 & 4.3 & 4.3 \\
\hline Gross external debt (percent of GDP) & 15.8 & 16.5 & 20.0 & 20.7 & 19.8 \\
\hline \multicolumn{6}{|l|}{ Exchange rate } \\
\hline Official exchange rate (kwanzas per U.S. dollar; end-of-period) & 75.0 & 75.1 & 89.4 & 92.6 & $\ldots$ \\
\hline Nominal effective exchange rate & -0.1 & 11.3 & -21.7 & $\ldots$ & $\ldots$ \\
\hline Real effective exchange rate & 7.9 & 21.7 & -14.0 & $\ldots$ & $\ldots$ \\
\hline \multicolumn{6}{|l|}{ Oil } \\
\hline Oil production (thousands of barrels per day) & 1,717 & 1,906 & 1,809 & 1,786 & 1,853 \\
\hline Angola oil price (average, U.S. dollars per barrel) & 72.4 & 93.9 & 60.9 & 75.1 & 72.6 \\
\hline
\end{tabular}

Sources: Angolan authorities, and IMF staff estimates and projections.

${ }^{1}$ In months of the following year's imports 
Table 2a. Angola: Fiscal Operations of the Central Government, 2008-11 ${ }^{1}$ (Billions of kwanza)

\begin{tabular}{|c|c|c|c|c|}
\hline & $\begin{array}{c}2008 \\
\text { Est. }\end{array}$ & $\begin{array}{c}2009 \\
\text { Est. }\end{array}$ & $\begin{array}{l}2010 \\
\text { Proj. }\end{array}$ & $\begin{array}{c}2011 \\
\text { Prog. } \\
\text { 4th Review }\end{array}$ \\
\hline Revenue & 3,217 & 1,848 & 3,271 & 3,565 \\
\hline Tax revenue & 3,070 & 1,704 & 3,109 & 3,387 \\
\hline Oil & 2,602 & 1,165 & 2,476 & 2,691 \\
\hline Non-oil & 468 & 539 & 632 & 696 \\
\hline Nontax revenue & 145 & 143 & 160 & 176 \\
\hline Grants & 2 & 1 & 2 & 2 \\
\hline Expenditures & 2,654 & 2,363 & 2,690 & 3,164 \\
\hline Current expenditures & 1,761 & 1,620 & 2,095 & 2,353 \\
\hline Personnel & 543 & 660 & 779 & 914 \\
\hline Goods and services & 539 & 383 & 586 & 716 \\
\hline Of which: oil related & & & 152 & 187 \\
\hline Interest payments & 94 & 130 & 163 & 158 \\
\hline Domestic & 60 & 90 & 93 & 104 \\
\hline External & 34 & 40 & 71 & 54 \\
\hline Transfers and Subsidies & 585 & 447 & 567 & 565 \\
\hline Of which: subsidies (oil \& utilities) & 443 & 356 & 444 & 401 \\
\hline Capital expenditures & 893 & 743 & 595 & 811 \\
\hline Of which: financed by external sources & 214 & 248 & 109 & 429 \\
\hline Overall balance (budget basis) & 564 & -515 & 581 & 401 \\
\hline Change in payments arrears (net) & 344 & 267 & -313 & -506 \\
\hline Domestic & 332 & 303 & -313 & -506 \\
\hline Payables (net) & 0 & 517 & -159 & -506 \\
\hline Receivables (net) & 332 & -214 & -154 & 0 \\
\hline External & 12 & -36 & 0 & 0 \\
\hline Overall balance (cash basis) & 908 & -249 & 268 & -105 \\
\hline Financing & -908 & 249 & -268 & 105 \\
\hline External financing (net) & 41 & 137 & -13 & 259 \\
\hline Domestic financing (net) & -949 & 111 & -255 & -154 \\
\hline \multicolumn{5}{|l|}{ Memorandum items: } \\
\hline Social expenditures & 743 & 600 & 807 & 997 \\
\hline Non-oil fiscal balance (budget basis) & $-2,038$ & $-1,680$ & $-1,743$ & $-2,103$ \\
\hline Non-oil primary fiscal balance (budget basis) & $-1,946$ & $-1,550$ & $-1,580$ & $-1,945$ \\
\hline Percent of non-oil GDP & -70.9 & -46.6 & -39.5 & -40.2 \\
\hline
\end{tabular}

Sources: Angolan authorities, and IMF staff estimates and projections.

${ }^{1}$ In 2010 Angola made a classification change to some oil related items; budget balances are not affected. Revenues are recorded on a commitment basis and expenditures are recorded on a cash basis. 
Table 2b. Angola: Fiscal Operations of the Central Government, 2008-11 ${ }^{1}$ (Percent of GDP)

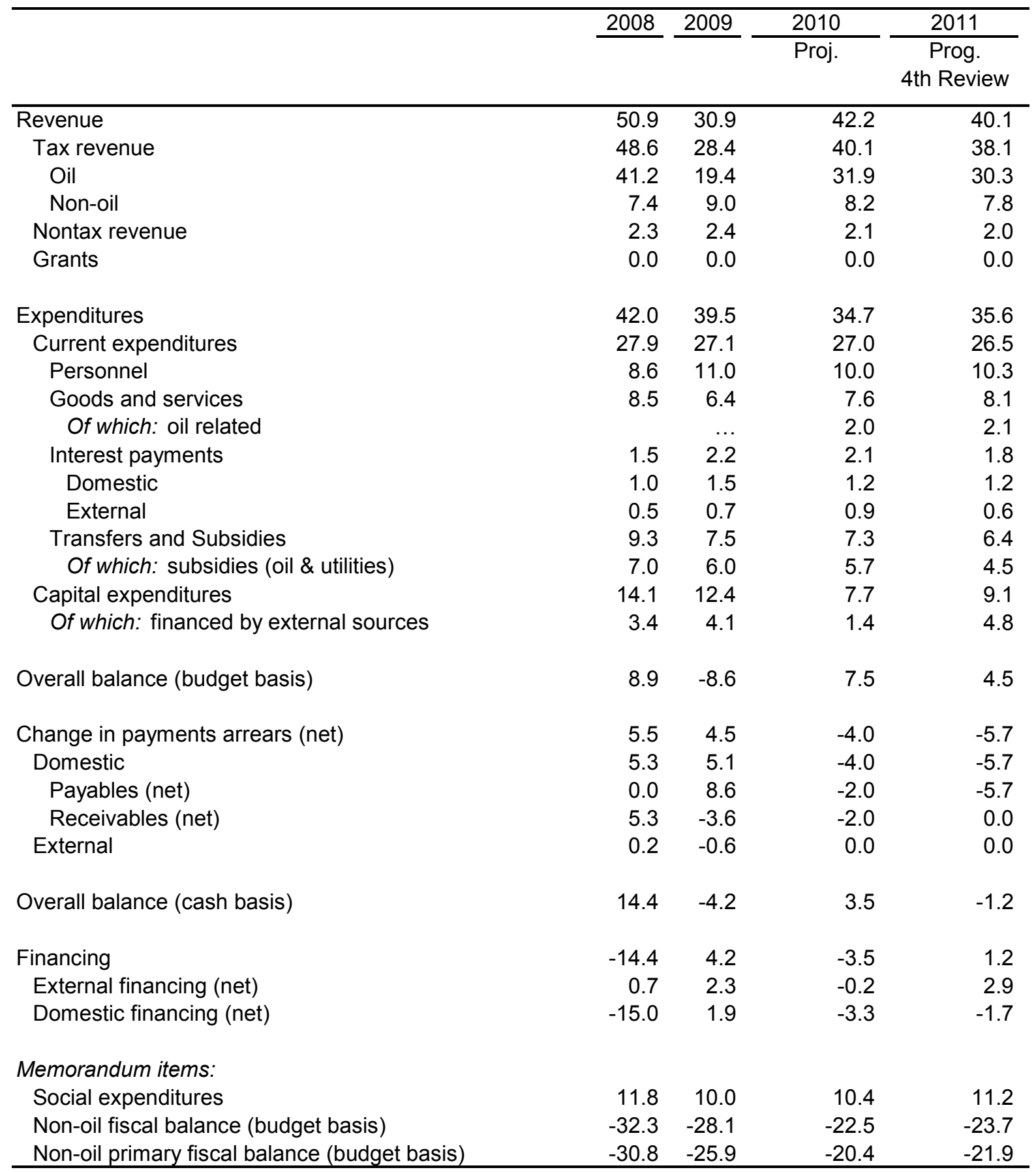

Sources: Angolan authorities, and IMF staff estimates and projections.

${ }^{1}$ In 2010 Angola made a classification change to some oil related items; budget balances are not affected. Revenues are recorded on a commitment basis and expenditures are recorded on a cash basis. 
Table 2c. Angola: Fiscal Operations of the Central Government, 2009-11 (Cumulative, Billions of kwanza)

\begin{tabular}{|c|c|c|c|c|c|c|c|c|c|}
\hline \multirow{4}{*}{$\begin{array}{l} \\
\text { Revenue }\end{array}$} & \multirow{4}{*}{$\begin{array}{r}\frac{2009}{Q 4} \\
1,848\end{array}$} & \multicolumn{4}{|c|}{2010} & \multicolumn{4}{|c|}{2011} \\
\hline & & \multirow[t]{2}{*}{ Q1 Est. } & \multirow[t]{2}{*}{ Q2 Est. } & \multirow[t]{2}{*}{ Q3 Est. } & \multirow[t]{2}{*}{ Q4 Proj. } & Q1 Prog. & Q2 Prog. & Q3 Prog. & Q4 Proj. \\
\hline & & & & & & \multicolumn{4}{|c|}{ 4th review } \\
\hline & & 774 & 1,666 & 2,531 & 3,271 & 814 & 1,695 & 2,585 & 3,565 \\
\hline Tax & 1,704 & 739 & 1,557 & 2,384 & 3,109 & 783 & 1,614 & 2,466 & 3,387 \\
\hline Oil & 1,165 & 610 & 1,277 & 1,943 & 2,476 & 635 & 1,294 & 1,980 & 2,691 \\
\hline Non-oil & 539 & 130 & 279 & 442 & 632 & 148 & 320 & 486 & 696 \\
\hline Non-tax & 143 & 35 & 109 & 145 & 160 & 30 & 80 & 118 & 176 \\
\hline Grants & 1 & 0 & 1 & 2 & 2 & 1 & 1 & 1 & 2 \\
\hline Expenditures & 2,363 & 506 & 1,163 & 1,795 & 2,690 & 616 & 1,338 & 2,080 & 3,164 \\
\hline Current expenditures & 1,620 & 441 & 917 & 1,383 & 2,095 & 466 & 988 & 1,531 & 2,353 \\
\hline Personnel & 660 & 151 & 315 & 488 & 779 & 181 & 380 & 594 & 914 \\
\hline Goods and services & 383 & 108 & 236 & 375 & 586 & 157 & 295 & 481 & 716 \\
\hline Interest payments & 130 & 51 & 76 & 90 & 163 & 22 & 80 & 107 & 158 \\
\hline Domestic & 90 & 11 & 30 & 37 & 93 & 14 & 59 & 76 & 104 \\
\hline External & 40 & 40 & 46 & 53 & 71 & 8 & 21 & 31 & 54 \\
\hline Transfers and Subsidies & 447 & 131 & 291 & 429 & 567 & 107 & 233 & 350 & 565 \\
\hline Capital expenditures & 743 & 65 & 246 & 412 & 595 & 149 & 351 & 549 & 811 \\
\hline Overall balance (budget basis) & -515 & 269 & 503 & 736 & 581 & 198 & 356 & 504 & 401 \\
\hline Change in payments arrears (net) & 267 & -85 & 51 & -278 & -313 & -386 & -502 & -502 & -502 \\
\hline Domestic & 303 & -86 & 47 & -278 & -313 & -386 & -502 & -502 & -502 \\
\hline External & -36 & 1 & 4 & 0 & 0 & 0 & 0 & 0 & 0 \\
\hline Overall balance (cash basis) & -249 & 183 & 554 & 458 & 268 & -188 & -145 & 2 & -101 \\
\hline Financing & 249 & -183 & -554 & -458 & -268 & 188 & 145 & -2 & 101 \\
\hline External financing (net) & 137 & 8 & 3 & -7 & -13 & 50 & 123 & 202 & 259 \\
\hline Domestic financing (net) & 111 & -192 & -558 & -451 & -255 & 137 & 22 & -204 & -158 \\
\hline \multicolumn{10}{|l|}{ Memorandum items: } \\
\hline Social expenditures & 600 & 132 & 326 & 558 & 807 & 185 & 424 & 631 & 997 \\
\hline Non-oil fiscal balance (budget basis) & $-1,680$ & -302 & -690 & $-1,078$ & $-1,743$ & -391 & -845 & $-1,336$ & $-2,103$ \\
\hline Non-oil primary fiscal balance (budget basis) & $-1,550$ & -252 & -614 & -987 & $-1,580$ & -369 & -765 & $-1,229$ & $-1,945$ \\
\hline
\end{tabular}

Sources: Angolan authorities, and IMF staff estimates and projections.

${ }^{1}$ In 2010 Angola made a classification change to some oil related items; budget balances are not affected. Revenues are recorded on a commitment basis and expenditures are recorded on a cash basis. 
Table 3. Angola: Balance of Payments, 2008-11

(Millions of U.S. dollars)

\begin{tabular}{|c|c|c|c|c|}
\hline & 2008 & 2009 & $\begin{array}{l}2010 \\
\text { Proj. }\end{array}$ & $\begin{array}{c}2011 \\
\text { Prog. } \\
\text { 4th review }\end{array}$ \\
\hline Current account & 7,194 & $-7,572$ & 480 & $-4,320$ \\
\hline Trade balance & 42,932 & 18,168 & 28,283 & 24,804 \\
\hline Exports, f.o.b. & 63,914 & 40,828 & 49,724 & 50,154 \\
\hline Crude oil & 61,666 & 39,271 & 47,703 & 47,913 \\
\hline Refined oil products and gas & 792 & 532 & 638 & 678 \\
\hline Diamonds & 1,210 & 814 & 1,121 & 1,238 \\
\hline Other & 247 & 212 & 262 & 325 \\
\hline Imports, f.o.b. & $-20,982$ & $-22,660$ & $-21,442$ & $-25,350$ \\
\hline Oil sector & $-5,713$ & $-4,326$ & $-5,255$ & $-5,596$ \\
\hline Non-oil sector & $-15,269$ & $-18,334$ & $-16,187$ & $-19,753$ \\
\hline Services (net) & $-21,810$ & $-18,546$ & $-18,524$ & $-19,480$ \\
\hline Receipts & 329 & 623 & 653 & 705 \\
\hline Payments & $-22,139$ & $-19,169$ & $-19,177$ & $-20,185$ \\
\hline Income (net) & $-13,718$ & $-6,823$ & $-8,866$ & $-9,222$ \\
\hline Receipts & 422 & 131 & 137 & 148 \\
\hline Payments & $-14,140$ & $-6,954$ & $-9,003$ & $-9,370$ \\
\hline Current transfers (net) & -210 & -370 & -413 & -422 \\
\hline Financial and capital account & 62 & 2,955 & 3,211 & 5,566 \\
\hline Capital transfers (net) & 12 & 4 & 0 & 0 \\
\hline Direct investment (net) ${ }^{1}$ & -891 & 2,199 & 2,321 & 2,919 \\
\hline Medium- and long-term loans & 3,833 & 561 & 1,070 & 2,217 \\
\hline Disbursements & 5,277 & 4,377 & 3,430 & 5,862 \\
\hline Amortization & $-1,443$ & $-3,817$ & $-2,360$ & $-3,645$ \\
\hline Other capital (net, incl. errors and omissions) & $-2,892$ & 192 & -179 & 430 \\
\hline Of which: errors and omissions & $-1,236$ & 457 & 0 & 0 \\
\hline Overall balance & 7,256 & $-4,616$ & 3,691 & 1,246 \\
\hline Change in gross international reserves (- increase) & $-6,673$ & 4,631 & $-3,000$ & $-1,700$ \\
\hline Exceptional items ${ }^{2}$ & -583 & -15 & -691 & 0 \\
\hline Financing gap & 0 & 0 & 0 & 454 \\
\hline Memorandum items: & \multicolumn{4}{|c|}{ (Percent of GDP unless otherwise indicated) } \\
\hline Current account & 8.5 & -10.0 & 0.6 & -4.8 \\
\hline Trade account & 51.0 & 24.1 & 33.5 & 27.6 \\
\hline Exports of goods and services & 76.3 & 54.9 & 59.8 & 56.5 \\
\hline Imports of goods and services & 51.2 & 55.4 & 48.2 & 50.6 \\
\hline External debt (billions of dollars) & 13.9 & 15.1 & 17.5 & 17.9 \\
\hline External debt & 16.5 & 20.0 & 20.7 & 19.8 \\
\hline NPV of external debt to net exports (percent) & 32.2 & 62.2 & 53.0 & 48.7 \\
\hline Debt-service ratio (percent of exports of goods \& services) & 4.3 & 12.5 & 7.7 & 10.2 \\
\hline Gross reserves (millions of U.S. dollars; end of period) & 17,878 & 13,238 & 16,238 & 17,938 \\
\hline Months of imports of goods and services ${ }^{3}$ & 5.1 & 3.9 & 4.3 & 4.3 \\
\hline Price of Angola's oil (U.S. dollars per barrel) & 91.7 & 60.7 & 75.1 & 72.6 \\
\hline
\end{tabular}

Sources: National Bank of Angola; and IMF staff estimates and projections.

${ }^{1}$ The net direct investment is largely affected by cost-recovery outflows by oil companies which depend on their oil profits.

${ }^{2}$ Mainly clearance of arrears.

${ }^{3}$ In months of next year's imports. 
Table 4. Angola: Monetary Authorities, 2008-11

(Billions of kwanzas; unless otherwise indicated)

\begin{tabular}{|c|c|c|c|c|c|c|c|c|c|c|}
\hline & \multirow[t]{3}{*}{2008} & \multirow[t]{3}{*}{2009} & \multicolumn{4}{|c|}{2010} & \multicolumn{4}{|c|}{2011} \\
\hline & & & \multirow[t]{2}{*}{ Mar } & \multirow[t]{2}{*}{ Jun } & \multirow[t]{2}{*}{ Sep } & \multirow{2}{*}{$\begin{array}{l}\text { Dec } \\
\text { Proj }\end{array}$} & Mar & Jun & Sep & Dec \\
\hline & & & & & & & \multicolumn{4}{|c|}{ Prog. 4th review } \\
\hline Net foreign assets & $1,314.1$ & $1,126.7$ & $1,278.4$ & $1,468.4$ & $1,487.7$ & $1,416.6$ & $1,446.4$ & $1,551.9$ & $1,693.7$ & $1,703.9$ \\
\hline Net international reserves & $1,315.4$ & $1,128.3$ & $1,280.1$ & $1,470.0$ & $1,489.3$ & $1,418.3$ & $1,448.1$ & $1,553.7$ & $1,695.6$ & $1,705.8$ \\
\hline Other foreign assets (net) & -1.3 & -1.6 & -1.7 & -1.6 & -1.6 & -1.7 & -1.7 & -1.8 & -1.8 & -1.9 \\
\hline Net domestic assets & -911.7 & -422.7 & -671.1 & -808.2 & -792.1 & -633.3 & -639.3 & -714.4 & -825.8 & -749.2 \\
\hline Domestic credit & $-1,025.1$ & -352.3 & -567.5 & -763.5 & -738.4 & -599.8 & -578.2 & -623.8 & -704.3 & -589.3 \\
\hline Net credit to the government & -934.4 & -294.2 & -440.2 & -569.8 & -444.5 & -419.1 & -406.9 & -512.6 & -673.9 & -645.3 \\
\hline Credit to financial institutions & 0.0 & 84.6 & 36.9 & 36.5 & 79.7 & 79.7 & 79.7 & 79.7 & 79.7 & 79.7 \\
\hline Credit to the private sector & 3.2 & 3.1 & 3.1 & 3.2 & 3.3 & 3.4 & 3.5 & 3.6 & 3.7 & 3.8 \\
\hline BNA bills held by commercial banks & -93.8 & -145.8 & -167.3 & -233.4 & -376.9 & -263.9 & -254.6 & -194.5 & -113.9 & -27.5 \\
\hline Other assets (net) & 113.4 & -70.4 & -103.6 & -44.7 & -53.8 & -33.4 & -61.0 & -90.6 & -121.4 & -159.9 \\
\hline Reserve money ${ }^{1}$ & 401.8 & 704.1 & 607.4 & 660.2 & 695.6 & 783.3 & 807.1 & 837.5 & 868.0 & 954.7 \\
\hline Currency in circulation & 168.4 & 213.9 & 168.3 & 162.0 & 166.4 & 202.3 & 214.0 & 225.6 & 237.2 & 248.8 \\
\hline Deposits of financial institutions & 231.6 & 488.2 & 437.1 & 461.7 & 492.6 & 544.3 & 556.5 & 575.3 & 594.1 & 669.3 \\
\hline Other deposits & 1.8 & 1.9 & 2.0 & 36.5 & 36.7 & 36.7 & 36.7 & 36.7 & 36.7 & 36.7 \\
\hline \multicolumn{11}{|l|}{ Memorandum items: } \\
\hline Official exchange rate (kwanzas per U.S. dollar; end of period) & 75.1 & 89.4 & 92.9 & 92.6 & 91.8 & $\ldots$ & & & & \\
\hline 12-month growth rate of currency in circulation & 48.3 & 27.1 & 20.6 & 4.4 & 0.6 & -5.4 & 27.2 & 39.2 & 36.8 & 23.0 \\
\hline 12-month growth rate of reserve money & 61.5 & 75.2 & 47.1 & 3.1 & 2.9 & 11.3 & 32.9 & 26.9 & 24.8 & 21.9 \\
\hline Gross international reserves (millions of U.S. dollars) & 17,878 & 13,238 & 14,086 & 16,182 & 17,306 & 16,238 & 16,336 & 17,150 & 18,140 & 17,938 \\
\hline
\end{tabular}

${ }^{1}$ In previous staff reports, reserve money was defined to be the sum of reserve money as defined here plus BNA bills held by commercial banks. Similarly, domestic credit did not include BNA bills held by commercial banks In previous staff reports. 
Table 5. Angola: Monetary Survey, 2008-11

(Billions of kwanzas; unless otherwise indicated)

\begin{tabular}{|c|c|c|c|c|c|c|c|c|c|c|}
\hline & \multirow[t]{3}{*}{2008} & \multirow[t]{3}{*}{2009} & \multicolumn{4}{|c|}{2010} & \multicolumn{4}{|c|}{2011} \\
\hline & & & \multirow[t]{2}{*}{ Mar } & \multirow[t]{2}{*}{ Jun } & \multirow[t]{2}{*}{ Sep } & \multirow{2}{*}{$\begin{array}{l}\text { Dec } \\
\text { Proj }\end{array}$} & Mar & Jun & Sep & Dec \\
\hline & & & & & & & \multicolumn{4}{|c|}{ Prog. 4th review } \\
\hline Net foreign assets & $1,481.2$ & $1,128.8$ & $1,202.7$ & $1,357.3$ & $1,434.8$ & $1,492.7$ & $1,526.3$ & $1,635.4$ & $1,814.2$ & $1,871.3$ \\
\hline Net international reserves (BNA) & $1,315.4$ & $1,128.3$ & $1,280.1$ & $1,470.0$ & $1,489.3$ & $1,418.3$ & $1,448.1$ & $1,553.7$ & $1,695.6$ & $1,705.8$ \\
\hline Other foreign assets (BNA) & -1.3 & -1.6 & -1.7 & -1.6 & -1.6 & -1.7 & -1.7 & -1.8 & -1.8 & -1.9 \\
\hline Commercial banks & 167.1 & 2.1 & -75.7 & -111.1 & -53.0 & 76.1 & 80.0 & 83.5 & 120.4 & 167.4 \\
\hline Net domestic assets & 509.1 & $1,409.1$ & $1,276.5$ & $1,137.8$ & $1,241.7$ & $1,614.1$ & $1,649.6$ & $1,591.7$ & $1,582.9$ & $1,888.2$ \\
\hline Net domestic credit & 595.0 & $1,728.1$ & $1,703.8$ & $1,625.8$ & $1,766.1$ & $2,014.1$ & $2,064.1$ & $2,022.4$ & $2,031.1$ & $2,397.1$ \\
\hline Credit to government (net) & -262.6 & 395.7 & 307.3 & 95.8 & 116.9 & 247.9 & 271.3 & 177.0 & 27.3 & 66.7 \\
\hline Credit to the economy & 857.6 & $1,332.5$ & $1,396.6$ & $1,530.0$ & $1,649.1$ & $1,766.2$ & $1,792.8$ & $1,845.4$ & $2,003.7$ & $2,330.4$ \\
\hline Other items (net) & -85.9 & -319.0 & -427.4 & -488.0 & -524.4 & -400.0 & -414.5 & -430.7 & -448.2 & -508.9 \\
\hline M3 & $1,990.3$ & $2,537.9$ & $2,479.2$ & $2,495.1$ & $2,676.4$ & $3,106.8$ & $3,175.9$ & $3,227.1$ & $3,397.1$ & $3,759.5$ \\
\hline Money and quasi money (M2) & $1,417.1$ & $2,303.8$ & $2,192.1$ & $2,219.2$ & $2,469.8$ & $2,834.8$ & $2,900.8$ & $2,949.7$ & $3,111.9$ & $3,458.5$ \\
\hline Money & $1,234.7$ & $1,635.3$ & $1,524.1$ & $1,532.6$ & $1,671.8$ & $1,903.3$ & $1,947.5$ & $1,980.4$ & $2,089.3$ & $2,322.0$ \\
\hline Currency outside banks & 126.1 & 169.7 & 133.5 & 122.1 & 159.8 & 134.1 & 137.2 & 139.5 & 147.2 & 163.6 \\
\hline Demand deposits & $1,108.7$ & $1,465.6$ & $1,390.7$ & $1,410.6$ & $1,512.0$ & $1,769.2$ & $1,810.3$ & $1,840.8$ & $1,942.1$ & $2,158.4$ \\
\hline Quasi-money & 182.4 & 668.5 & 667.9 & 686.6 & 797.9 & 931.6 & 953.2 & 969.3 & $1,022.6$ & $1,136.5$ \\
\hline Repurchase agreements & 573.1 & 234.1 & 287.1 & 275.9 & 206.7 & 272.0 & 275.2 & 277.5 & 285.1 & 301.0 \\
\hline \multicolumn{11}{|l|}{ Memorandum items: } \\
\hline 12-month growth rate of M2 (percent) & 66.0 & 62.6 & 69.7 & 28.7 & 29.8 & 23.0 & 32.3 & 32.9 & 26.0 & 22.0 \\
\hline Credit to the economy (12-month percentage change) & 70.2 & 55.4 & 54.8 & 53.5 & 51.5 & 32.6 & 28.4 & 20.6 & 21.5 & 31.9 \\
\hline Money multiplier (M2/reserve money) & 3.5 & 3.3 & 3.6 & 3.4 & 3.6 & 3.6 & 3.6 & 3.5 & 3.6 & 3.6 \\
\hline
\end{tabular}

Sources: National Bank of Angola (BNA) and IMF staff estimates and projections. 
Table 6. Angola: Illustrative Medium-Term Scenario, 2009-15

\begin{tabular}{|c|c|c|c|c|c|c|c|}
\hline & 2009 & 2010 & 2011 & 2012 & 2013 & 2014 & 2015 \\
\hline & & \multicolumn{6}{|c|}{ Projection } \\
\hline \multicolumn{8}{|l|}{ Real economy (percent change) } \\
\hline Real GDP & 2.4 & 2.3 & 6.4 & 9.7 & 6.5 & 6.4 & 6.4 \\
\hline Oil sector & -5.1 & -1.3 & 3.8 & 10.6 & 3.0 & 3.0 & 3.0 \\
\hline Non-oil sector & 8.1 & 4.7 & 8.1 & 9.2 & 8.6 & 8.3 & 8.2 \\
\hline Consumer price index (annual average) & 13.7 & 14.5 & 13.3 & 11.0 & 8.9 & 6.5 & 6.0 \\
\hline Consumer price index (end of period) & 14.0 & 15.0 & 10.8 & 11.2 & 7.0 & 6.0 & 6.0 \\
\hline Gross domestic product (billions of kwanzas) & 5,989 & 7,756 & 8,879 & 11,259 & 13,202 & 14,933 & 16,659 \\
\hline Of which: Non-oil gross domestic product (billions of kwanzas) & 3,327 & 3,999 & 4,834 & 5,967 & 7,067 & 8,158 & 9,360 \\
\hline Gross domestic product (millions of U.S. dollars) & 75,508 & 84,304 & 89,961 & 102,351 & 110,847 & 119,406 & 130,016 \\
\hline GDP per capita (U.S. dollars) & 4,082 & 4,425 & 4,584 & 5,064 & 5,324 & 5,568 & 5,886 \\
\hline \multicolumn{8}{|l|}{ Central government (percent of GDP) } \\
\hline Total revenues & 30.9 & 42.2 & 40.1 & 41.5 & 41.4 & 41.6 & 41.7 \\
\hline Of which: Oil & 19.4 & 31.9 & 30.3 & 31.0 & 30.8 & 30.8 & 30.5 \\
\hline Total expenditures & 39.5 & 34.7 & 35.6 & 34.3 & 34.9 & 35.3 & 35.7 \\
\hline Of which: Capital expenditures & 12.4 & 7.7 & 9.1 & 10.0 & 10.4 & 10.7 & 11.0 \\
\hline Overall balance (budget basis) & -8.6 & 7.5 & 4.5 & 7.2 & 6.6 & 6.4 & 6.0 \\
\hline Non-oil primary fiscal balance (excluding grants, budget basis) & -25.9 & -20.4 & -21.9 & -20.9 & -20.9 & -21.0 & -21.0 \\
\hline \multicolumn{8}{|l|}{ Money and cre dit (end-of-period, percent change) } \\
\hline Broad money & 27.5 & 22.4 & 21.0 & 21.4 & 16.7 & 15.7 & 15.7 \\
\hline Velocity (non-oil GDP/average M2) & 1.8 & 1.6 & 1.5 & 1.6 & 1.5 & 1.5 & 1.5 \\
\hline \multicolumn{8}{|l|}{ Balance of payments } \\
\hline Goods and services trade balance (percent of GDP) & -0.5 & 11.6 & 5.9 & 9.9 & 9.2 & 8.1 & 6.9 \\
\hline Exports, f.o.b. (percent change, in U.S. dollars) & -36.1 & 21.8 & 0.9 & 17.8 & 7.8 & 6.1 & 6.4 \\
\hline Of which: Oil & -36.3 & 21.5 & 0.5 & 17.6 & 7.7 & 6.0 & 6.2 \\
\hline Imports, f.o.b. (percent change, in U.S. dollars) & 8.0 & -5.4 & 18.2 & 11.4 & 9.5 & 9.0 & 9.1 \\
\hline Current account balance (percent of GDP) & -10.0 & 0.6 & -4.8 & 0.2 & -0.3 & -1.4 & -2.0 \\
\hline Gross international reserves (end-of-period, millions of U.S. dollars) & 13,238 & 16,238 & 17,938 & 21,621 & 25,266 & 28,476 & 31,558 \\
\hline In months of imports of goods and services ${ }^{1}$ & 3.9 & 4.3 & 4.3 & 4.8 & 5.2 & 5.4 & 5.6 \\
\hline Gross external debt (percent of GDP) & 20.0 & 20.7 & 19.8 & 19.4 & 19.3 & 19.6 & 19.2 \\
\hline \multicolumn{8}{|l|}{ Oil } \\
\hline Oil production (thousands of barrels per day) & 1,809 & 1,786 & 1,853 & 2,050 & 2,112 & 2,175 & 2,240 \\
\hline Angola oil price (average, U.S. dollars per barrel) & 60.9 & 75.1 & 72.6 & 77.0 & 80.5 & 82.7 & 85.2 \\
\hline
\end{tabular}

Sources: Angolan authorities, and IMF staff estimates and projections.

${ }^{1}$ In months of the following year's imports. 
Table 7. Angola: Banking System Financial Soundness Indicators 2003-10

(Percent, end-of-period)

\begin{tabular}{|c|c|c|c|c|c|c|c|c|}
\hline & 2003 & 2004 & 2005 & 2006 & 2007 & 2008 & 2009 & Sep-10 \\
\hline \multicolumn{9}{|l|}{ Capital adequacy } \\
\hline Regulatory capital to risk-weighted assets & 18.1 & 19.6 & 19.4 & 18.5 & 21.9 & 19.5 & 19.5 & 17.5 \\
\hline Capital (net worth) to risk-weighted assets & 11.8 & 13.5 & 16.1 & 15.3 & 15.0 & 16.0 & 14.7 & 14.3 \\
\hline \multicolumn{9}{|l|}{ Asset quality } \\
\hline Foreign exchange loans to total loans & 27.8 & 55.7 & 72.7 & 71.4 & 69.9 & 61.9 & 65.3 & 64.5 \\
\hline Nonperforming loans to gross loans & 9.0 & 8.1 & 6.4 & 4.8 & 2.9 & 2.4 & 2.6 & 7.1 \\
\hline Provision as percent of capital (net worth) & 13.0 & 13.6 & 9.2 & 8.8 & 4.9 & $\ldots$ & 11.6 & 21.1 \\
\hline \multicolumn{9}{|l|}{ Sectoral distribution of credits } \\
\hline Credit to public sector to total credit & 7.7 & 5.2 & 10.0 & 7.1 & 8.1 & 10.1 & 9.4 & 10.8 \\
\hline Credit to private sector to total credit & 92.3 & 94.7 & 89.1 & 92.6 & 91.9 & 89.9 & 90.6 & 89.3 \\
\hline \multicolumn{9}{|l|}{ Net profit } \\
\hline Return on assets (ROA) & 4.7 & 4.1 & 3.1 & 2.7 & 2.7 & 2.4 & 3.4 & 2.6 \\
\hline Return on equity (ROE) & 27.0 & 24.3 & 34.2 & 28.8 & 23.6 & 26.5 & 36.5 & 28.5 \\
\hline Expense/income & 82.2 & 87.7 & 62.5 & 64.5 & 73.6 & $\ldots$ & 45.5 & 41.9 \\
\hline \multicolumn{9}{|l|}{ Interest rate spread (deposit money banks) } \\
\hline Lending rate minus demand deposit rates & 71.1 & 62.6 & 32.3 & 18.9 & 9.4 & 9.0 & 9.0 & 12.8 \\
\hline Saving deposit rates & 47.1 & 46.0 & 2.4 & 3.2 & 8.2 & 8.6 & 8.6 & 9.6 \\
\hline Interest margin to gross income & 103.8 & 116.3 & 58.6 & 47.4 & 56.1 & 56.9 & 26.7 & 67.8 \\
\hline \multicolumn{9}{|l|}{ Liquidity } \\
\hline Liquid assets/total assets & 97.0 & 63.9 & 47.1 & 34.4 & 34.2 & 42.6 & 31.4 & 24.5 \\
\hline Liquid assets/short term liabilities & 85.3 & 78.5 & 84.1 & 59.8 & 63.1 & 93.1 & 56.9 & 42.1 \\
\hline Loan/deposits & 38.7 & 45.8 & 39.9 & 45.4 & 54.0 & 53.7 & 55.8 & 66.9 \\
\hline Foreign exchange liabilities/total liabilities & 46.5 & 45.0 & 55.1 & 59.2 & 54.8 & 48.0 & 54.9 & 53.6 \\
\hline \multicolumn{9}{|l|}{ Sensitivity to market risk } \\
\hline Net open position in foreign exchange to capital & 41.6 & 64.1 & 53.1 & 74.34 & 33.0 & 45.5 & 88.8 & $60.0^{1}$ \\
\hline
\end{tabular}

Source: BNA's Banking Supervision Directorate.

${ }^{1}$ As of August 2010. 
Table 8. Angola: Indicators of Capacity to Repay the Fund, 2009-16

(Million of SDRs, unless otherwise indicated)

\begin{tabular}{lrrrrrrrr}
\hline & 2009 & 2010 & 2011 & 2012 & 2013 & 2014 & 2015 & 2016 \\
\hline Disbursements & 229.0 & 343.6 & 286.3 & 0.0 & 0.0 & 0.0 & 0.0 & 0.0 \\
Repayments & 0.0 & 0.0 & 0.0 & 0.0 & 171.8 & 361.5 & 257.7 & 68.0 \\
Charges/interest & 0.0 & 3.7 & 11.3 & 11.8 & 11.3 & 8.2 & 3.3 & 0.6 \\
Stock of outstanding use of Fund resources & 229.0 & 572.6 & 858.9 & 858.9 & 687.1 & 325.7 & 68.0 & 0.0 \\
Memorandum items: & & & & & & & & \\
Debt service (percent) & & & & & & & \\
$\quad$ Payments to the Fund/Exports & & & & & & & \\
$\quad$ Payments to the Fund/Quota & 0.0 & 0.0 & 0.0 & 0.0 & 0.4 & 0.8 & 0.5 & 0.1 \\
$\quad$ Payments to the Fund/GDP & 0.0 & 1.3 & 3.9 & 4.1 & 64.0 & 129.1 & 91.2 & 23.9 \\
$\quad$ Payments to the Fund/Reserves & 0.0 & 0.0 & 0.0 & 0.0 & 0.3 & 0.5 & 0.3 & 0.1 \\
Outstanding use of Fund resources (percent) & 0.0 & 0.0 & 0.1 & 0.1 & 1.1 & 2.0 & 1.3 & 0.3 \\
$\quad$ & & & & & & & 0.3 \\
$\quad$ Outstanding UFR/Exports & 0.9 & 1.7 & 2.6 & 2.2 & 1.6 & 0.7 & 0.1 & 0.0 \\
$\quad$ Outstanding UFR/Quota & 80.0 & 200.0 & 300.0 & 300.0 & 240.0 & 113.8 & 23.8 & 0.0 \\
$\quad$ Outstanding UFR/GDP & 0.5 & 1.0 & 1.5 & 1.3 & 0.9 & 0.4 & 0.1 & 0.0 \\
$\quad$ Outstanding UFR/Reserves & 2.7 & 5.3 & 7.3 & 6.0 & 4.1 & 1.7 & 0.3 & 0.0 \\
\hline
\end{tabular}

Source: IMF staff estimates. 
Table 9. Angola: Reviews and Disbursements under the 27-month Stand-By Arrangement

\begin{tabular}{|c|c|c|c|}
\hline \multirow{2}{*}{ Availability date } & \multicolumn{2}{|c|}{ Amount of Purchase } & \multirow[b]{2}{*}{ Conditions } \\
\hline & Percent of quota & Million of SDRs & \\
\hline Purchased & 80.0 & 229.04 & Upon approval of the SBA \\
\hline Purchased & 40.0 & 114.52 & $\begin{array}{l}\text { Upon completion of the 1st review and observance of end-December } 2009 \\
\text { performance criteria }\end{array}$ \\
\hline Purchased & 80.0 & 229.04 & $\begin{array}{l}\text { Upon completion of the } 2 \text { nd and the } 3 \text { rd reviews and observance of end- } \\
\text { June } 2010 \text { performance criteria }\end{array}$ \\
\hline December 15, 2010 & 40.0 & 114.52 & $\begin{array}{l}\text { Upon completion of the 4th review and observance of end-December } 2010 \\
\text { performance criteria (in light of the delayed program review) }\end{array}$ \\
\hline June 15, 2011 & 30.0 & 85.89 & $\begin{array}{l}\text { Upon completion of the 5th review and observance of end-March } 2011 \\
\text { performance criteria }\end{array}$ \\
\hline December 15, 2011 & 30.0 & 85.89 & $\begin{array}{l}\text { Upon completion of the 6th review and observance of end-September } 2011 \\
\text { performance criteria }\end{array}$ \\
\hline Total & 300.0 & 858.9 & \\
\hline
\end{tabular}




\section{APPENDiX I. ANGOla: LetTER OF INTENT}

January 10, 2011

Mr. Dominique Strauss-Kahn

Managing Director

International Monetary Fund

$70019^{\text {th }}$ Street N.W.

Washington, D.C. 20431

USA

Dear Mr. Strauss-Kahn:

1. The Angolan government continues to make good progress in achieving key objectives under its stabilization program, which is being supported by the IMF under a Stand-By Arrangement (SBA). The economy is gradually recovering from the disruption caused by the collapse of world oil prices: foreign reserves are being rebuilt, the fiscal position has improved sharply, and the exchange market has stabilized. The outlook for 2011 is generally favorable, although we are well aware of the uncertainties surrounding the global economic outlook and the corresponding need to maintain a cautious macroeconomic policy stance.

2. Three of the quantitative performance criteria for end-September 2010 were missed, in part for technical reasons and in part because of the impact of our third quarter arrears clearance operation on the government cash position-an event that had not been allowed for when the original quantitative targets were set:

- $\quad$ The target of accumulating no new arrears (as defined in relation to the contracts with our suppliers, rather than budget law) proved to be overly ambitious, given the mechanics of our government payments system and the information it generates: we have moved to clear the bulk of the intra-year accumulation of accounts payable by end-December, have sharply reduced the stock of 2008-09 arrears via a large arrears clearance operation, and are putting in place procedures for 2011 that will tightly limit any scope for new arrears. We are requesting a change in the technical specification of this performance criterion to align the measurement of performance to the build-up of accounts payable, as captured by our existing information systems.

- $\quad$ The ceiling on net domestic credit extended by the BNA was missed by some $\mathrm{Kz} 160$ billion, in large part reflecting the impact of the large arrears clearance operation on government deposits but also the settlement (rather than rolling over) of government domestic debt; that said, the BNA expanded its liquidity absorption 
operations to contain the growth of base money well within program targets and we expect broad money growth in 2010 to be below the original program target. The non-observance of this performance criterion in part reflected a flawed specification of the target variable; we are requesting a change in the technical specification of this performance criterion to make full allowance for the effects of BNA sterilization operations.

- $\quad$ The ceiling on banking system credit to the government was missed by a modest margin, some $\mathrm{Kz} 70$ billion. This nonobservance did not stem from an overly loose fiscal stance; the non-oil primary deficit (NOPD) is running well below programmed levels. Instead, the breach stemmed from the large cash payments, some $\mathrm{Kz} 227$ billion, made in the third quarter to clear 2008-09 payments arrears - an important move by the government that had not been adequately allowed for when the original financial targets for the year were set.

3. Looking to the end-December performance targets, we anticipate that the performance criteria on the non-accumulation of new arrears, the net domestic credit extended by the BNA, and on banking system credit to the government are likely to have been missed. In the first two cases, the explanatory factors listed above carry through to the end of the year-although there is a reasonable chance that our efforts to clear accounts payable accumulated through end-September will result in a net decline in the stock of accounts payable over the fourth quarter (implying that the target would have been met). As to the likely nonobservance of the end-December target for banking system credit to the government, this does not reflect an overly loose fiscal stance; we expect to have achieved a full-year non-oil primary deficit (NOPD) that is some Kz 350 billion below target. Instead, nonobservance reflects unanticipated financing-side shifts, including higher-thanprogrammed arrears clearance over the year and a sizeable shortfall in non-bank financing (a residual category), along with a significant and unintended tightening of the full-year target resulting from deviations between forecasts and outcomes of end-2009 bank balance sheets. Looking to 2011, our arrears clearance plans are fully factored into our financial program, and we expect to meet our financial targets.

4. We therefore request waivers for non-observance of these performance criteria at end-December, given the strength of program performance, the corrective measures in place to maintain tight control on spending commitments, and the explanatory factors cited above. For the end-December performance criteria on net international reserves, we request a waiver of applicability on the grounds that program performance has been strong, the relevant information is not available, and there is no clear evidence that these criteria have not been met.

5. We are committed to implementing the program described in the attached Memorandum of Economic and Financial Policies (MEFP). Our macroeconomic objectives for 2011 are to continue the process of rebuilding reserves; to gradually rein in inflation; and to raise public capital spending to address deep-rooted infrastructure 
requirements. Building on the progress made thus far, we plan a new set of reform measures for 2011. The specific quantitative targets and structural measures embodied in our program are summarized in Tables 1 and 2.

6. The remainder of the program will be monitored through a mix of quantitative performance criteria, indicative targets and structural benchmarks. The quantitative performance criteria on external debt contracted or guaranteed by the central government, and the non-accumulation of external arrears, will be continuous for the duration of the Stand-By Arrangement. All other performance criteria will be evaluated at end-March 2011 in the context of the $5^{\text {th }}$ review to be conducted in June 2011, and at end-September 2011 in the context of the $6^{\text {th }}$ review to be conducted in December 2011. Indicative targets for endJune will also be closely monitored under the program.

7. We will regularly update the IMF on economic and policy developments and will provide the data needed for adequate monitoring of the program. The government will continue its policy dialogue with the IMF and is prepared to take any further measures as appropriate to meet its program objectives. We will consult with the Fund ahead of any revisions to the measures outlined in the MEFP. To provide a clear public statement of our policy intentions, we authorize the IMF to publish this letter of intent, the attached MEFP, and the associated staff report.

Sincerely yours,

$/ \mathrm{s} /$

Carlos Maria da Silva Feijó

Minister of State and Chief of Civil Service
$/ \mathrm{s} /$

Carlos Alberto Lopes

Minister of Finance

Attachments: - Memorandum of Economic and Financial Policies

- Technical Memorandum of Understanding 


\section{ATtACHMENT I}

\section{Angola: Memorandum of Economic and Financial Policies}

\section{Recent Developments}

1. Angola is making steady progress in managing recovery from the collapse of oil prices that was triggered by the global economic crisis. The exchange rate has stabilized, reserves are being rebuilt, and the fiscal position has been strengthened by reining in spending levels. The large domestic arrears incurred during the crisis period are now being reduced, and we expect to clear the outstanding arrears by end-March 2011. Central controls over the undertaking of spending commitments have been intensified to constrain the emergence of new arrears.

2. Economic performance during 2010 has been broadly encouraging, although output is recovering at a slower-than-anticipated pace, reflecting both short-term operational difficulties in the oil sector and a stronger-than-anticipated slowdown in some sectors in response to the sizeable fiscal adjustment. GDP growth in 2010 is projected to be some $2 \frac{1}{2}$ percent, with non-oil GDP expanding at close to 5 percent. Growth should pick up in 2011 , as oil output rebounds and non-oil output returns towards pre-crisis growth rates. The medium-term outlook is favorable, as oil production ramps up in new fields from 2012 and a large liquid natural gas plant comes on stream. The pace of inflation, running at around 15 percent, has remained little changed through the economic downturn, notwithstanding a significant exchange rate adjustment.

3. We have met the quantitative performance criteria set for end-September 2010, with three exceptions. The factors contributing to the nonobservance of these targets, and the possible nonobservance of these targets as of end-December 2010, are discussed above in our letter to the Managing Director. Implementation of our reform program continues, with most structural benchmarks either met (some with delays) or close to being met. Our AfDBsupported program to strengthen project appraisal at the Ministry of Planning has been put on hold due to unexpected delays (outside our control) in obtaining AfDB approval, but we hope that these difficulties will be resolved by end-May 2011. Preparing quarterly budget execution reports that include quasi-fiscal operations for submission to the National Assembly and eventual publication has been held up by capacity constraints; we hope to resolve these issues by mid-2011.

\section{The 2011 Budget}

4. Budget implementation in 2010 has been lower than programmed, in part reflecting our efforts to contain outlays with a view to matching spending levels with available cash balances: outlays on goods and services and capital projects are likely to come in some 16 percent below our (revised) budgeted levels. This expenditure restraint provided us with 
the room to begin strengthening our financial position - to rebuild deposits at the BNA, to pay down expensive debt, and to clear arrears — but it cannot be sustained indefinitely.

5. We are framing our 2011 budget discussions around the dual objectives of rebuilding external reserves and raising outlays on capital spending to address key infrastructure weaknesses, notably deficiencies in our roads system. Given the uncertainties surrounding the global economic outlook, we are taking a cautious stance in regard to projected revenues from the oil sector. We envisage an aggregate spending envelope not exceeding 3.16 trillion Kwanza (about 36 percent of GDP), of which one-quarter of the outlays will go to capital projects. We intend to meet our commitment to allocate 30 percent of budget resources to social spending. To provide space for additional capital spending, we intend in the coming months to hire new professional staff at the Tax and Customs Directorates with the aim of sharply intensifying our tax collection efforts. We expect to record a budget surplus on the order of $4 \frac{1}{2}$ percent of GDP in 2011, down from a projected $7 \frac{1}{2}$ percent of GDP in 2010, with the surplus being used both to build foreign reserves and to provide cash to help settle the remainder of our verified arrears from 2008-09. These remaining arrears will be settled via a combination of cash payments and issuance of securities.

6. Should oil prices evolve more favorably than we have assumed, we may revisit the expenditure envelope at mid-year with a view to dedicating a significant share of the additional resources towards new infrastructure projects that are assessed as being soundly-designed and likely to generate high social and economic rates of return. As part of that mid-year review, we would consult with IMF staff on our spending plans.

\section{Clearing Domestic Payment Arrears}

7. The fall in oil prices from late-2008 yielded a sharp drop in government revenues, requiring a commensurate reduction in spending levels. Large spending cuts were introduced in the 2009 supplementary budget but, against a backdrop of deep uncertainty and intense exchange market pressures, market-based financing of the government's remaining payment imbalances proved difficult, resulting in the emergence of arrears to domestic suppliers, primarily, but not exclusively, in the construction sector. Many construction projects already underway continued to be implemented, leading to further accumulation of payment arrears.

8. To limit the accumulation of new arrears, the contracting of new public works was suspended at the outset of 2010. As government finances improved over the course of the year, we initiated the clearance of outstanding arrears, settling some 50 percent of the outstanding balance of verified pre-2010 payments arrears (including all arrears to small creditors) with cash payments, and have reached substantive agreement with the remaining creditors on a final settlement to be implemented by end-March 2011 (structural benchmark). We have cleared the bulk of the accounts payable accumulated in 2010, using budgetary resources. 


\section{Monetary and Exchange Rate Policies}

9. As part of the process of restoring market confidence, we have sought to stabilize the Kwanza-dollar exchange rate over the past year, using elevated interest rates to support the domestic currency. As exchange market pressures have eased in recent months, interest rates on short-term central bank paper have declined, but we stand ready to tighten the monetary stance if intense pressures on the Kwanza were to resume. Over time, as the financial situation normalizes, we intend to allow greater flexibility of the exchange rate, including gradual adjustment of the value of the Kwanza over time in line with market fundamentals.

10. Our monetary program for 2011 is constructed around the objectives of achieving an accumulation of at least US $\$ 1.7$ billion in gross international reserves while bringing down inflation to around 12 percent. Our current assessment is that monetary growth on the order of 22 percent over the course of the year is consistent with our inflation and nominal GDP growth targets, and we will manage the growth of base money in line with this aggregate target for M2 growth. That said, we can envisage circumstances where the process of financial deepening observed in the pre-crisis period (through end-2008) may resume as conditions normalize; with that in mind, we intend to review our monetary program at midyear to see if it remains consistent with our broader macroeconomic objectives, and will recalibrate the monetary targets if warranted. As part of that mid-year review, we will consult with IMF staff on the appropriate modifications to our monetary targets.

11. Measures have been taken to improve the working of the foreign exchange auction: the time window for conducting the auction has been narrowed, while the intra-day timing of the auction has now been fully standardized. The BNA has also improved its capacity to forecast likely market needs for foreign currency, thereby reducing unnecessary volatility. We will continue to use our outlier policy sparingly in the foreign exchange auction, applying it only to bids that raise prudential or regulatory compliance concerns.

12. Liquidity management is the responsibility of the BNA, working in close coordination with the Treasury. During 2010, the BNA has undertaken this burden alone, increasing its issuance of short-term central bank paper as the Treasury exited the bills market, repaying the entire outstanding stock of Treasury bills by end-September. We have moved in recent weeks to redress this imbalance, issuing Treasury bills both to finance upcoming outlays by the Treasury and to allow the BNA to reduce its presence in the market. Consistent with IMF TA advice, we intend to move rapidly towards a situation where central bank paper is exclusively short-term in nature (less than 91 days), with the Treasury active only in the longer end of the bills market (91-364 day maturities). The sale of foreign currency to absorb liquidity will be limited to levels consistent with the achievement of our foreign reserve objectives. 


\section{The Financial System}

13. Angolan banks have not been severely impaired by the financial instability of the last two years, although non-performing loans (system-wide), as a share of the loan portfolio, have risen from 2.6 percent to 7.1 percent, triggered in part by the financial distress of firms that are owed substantial sums by the government. With yields on public sector paper rising sharply during the crisis period, many banks sought to shift available funds into government paper, partly constraining the availability of new credit to the private sector, but this situation is expected to reverse as market conditions normalize.

14. While the financial system has weathered the economic crisis, we recognize the need to improve the supervisory capability of the BNA and to modify regulations, notably those relating to credits denominated in foreign currency. The BNA has already tightened the provisioning guidelines covering these loans; and intends, by end-March 2011, to modify capital adequacy regulations to increase the risk-weighting attached to such credits.

Separately, the BNA has moved to tighten regulations on the net open position of banks, with a phased reduction from the initial limit of 100percent of capital to 20 percent by mid-2012. The BNA also intends to eliminate the bias against local currency deposits by gradually reducing the present 25 percent reserve requirement on local currency deposits to the 15 percent level applied to foreign currency deposits. The BNA has hired a management consulting firm to assist in conducting a comprehensive review of banking regulations, aimed at identifying the changes needed to incorporate international best practice.

15. We look forward to conducting a comprehensive assessment of our financial system under the IMF-World Bank Financial Sector Assessment Program, expected to commence in March 2011.

\section{Our Reform Agenda}

16. Our reform agenda for the near term includes: a) administrative reforms to strengthen public financial management and policy formulation; b) initiating a comprehensive overhaul of our domestic tax regime; c) development of fiscal rules and an associated sovereign wealth fund that would manage budgetary savings to facilitate both expenditure-smoothing and the transfer of oil wealth to future generations; and d) measures to improve the business climate.

17. At the Finance Ministry, we are making resources available to strengthen the capacity of the newly-established debt management unit and aim to finalize a debt management strategy by end-March 2011 (structural benchmark). We are also building internal capacity to screen and manage public private partnerships (PPPs), with the aim, in due course, to make strategic use of such arrangements to supplement state activities in areas such as power generation, urban water supply, and road maintenance; the relevant legislation, now in the National Assembly, is expected to be approved by end-March 2011. We are looking to an AfDB-financed project to strengthen project appraisal and monitoring capacity at the Ministry of Planning, which we see as being crucial to ensuring effective screening of 
projects, thereby limiting approval only to well-designed projects that have high economic and social rates of return. To strengthen oversight of public enterprises (PEs), we have established a new Institute for Public Enterprises, under the wing of the Ministry of Economy; a new PE Law, expected to be submitted for consideration by the National Assembly during the first quarter of 2011 (structural benchmark), would require enterprises to supply quarterly reports to the Institute and to produce externally audited annual accounts that will later be made public. The proposed law would also lay the basis for introducing performance contracts as a tool for guiding and improving management performance in PEs.

18. We are putting in place an overarching legal framework to lay the basis for comprehensive tax reforms, and expect the associated legislation, currently under consideration by the National Assembly, to be put in place by end-March 2011. Our tax reform program is a multi-year project, aimed at modernizing tax administration, improving tax compliance, broadening the tax base while scaling back tax exemptions, and putting in place efficient legal processes for handling tax cases. We have contracted an international management consultancy to work with us in designing a reform program and fleshing out a road map for implementation; key features of the program are to include the creation of a unified tax administration, modernization of IT capabilities, and the provision of substantial resources to expand and upgrade the skills of the workforce. We expect to have completed a time-bound action plan for the reform program for submission to cabinet by end-June 2011 (structural benchmark). As immediate measures to boost revenue collections, we are undertaking a recruitment drive to hire new professional staff; intensifying managerial oversight to boost performance; and plan to introduce performance-based assessment to motivate collection efforts. We expect that these measures will yield significant results within the coming year. We would welcome IMF technical assistance in the areas of tax policy reform and modernization of administration.

19. Looking to the medium-term, we see a need to enact policies that would put an end to the disruption caused by the boom-bust cycle that is associated with oil price volatility. We are considering alternative fiscal rules, perhaps to be formalized in legislation, which would help smoothen public spending levels over the oil price cycle and prevent the sharp disruption of spending plans recorded in 2009-10. We are reviewing the international experience with such rules in oil-dependent economies, and would welcome a detailed review of such experience from Fund staff as input. Implementation of an explicit public savings rule would generate funds to be managed under our proposed Sovereign Wealth Fund, the design of which is currently under consideration by the cabinet.

20. Diversification of economic activity beyond the oil sector will necessitate, inter alia, a major improvement in the business environment. Reform efforts are underway to address key deficiencies, including weak contract enforcement, difficulties in transferring property, and multiple layers of regulation. A reform program has been initiated to address weaknesses in the judicial system, including new training programs for magistrates and the expansion of the court system across the entire country. The land registry in Luanda has been substantially 
upgraded, accelerating the process of transferring property. Licensing in the trade sector has been markedly simplified, and a broader review of licensing processes aimed at identifying areas for deregulation is to be undertaken in 2011. Transformation of the climate for private business will not happen quickly, but we are committed to pushing ahead as speedily as conditions will allow.

\section{Transparency and Safeguards Measures}

21. We remain committed to increasing the transparency of operations of public entities, in part to increase the accountability of these entities to the public. Following on the publication of audits for 2007 and 2008, Sonangol's 2009 external audit has recently been published (structural benchmark). We intend to commence regular publication of external audits for other major state enterprises, starting first with Angola Telecom, Caminho de Ferro de Luanda (Luanda railways), and Empresa Pública de Água de Luanda (the water company of Luanda) whose audits have now been published. We are also currently laying the basis for conducting an external audit of Endiama (the state diamond company) covering 2010, and would expect to publish the results of this audit by end-September 2011. Publication of quarterly budget execution reports is expected to commence on a regular basis by mid-2011; a report covering the first semester of 2010 has been sent to the National Assembly and will be published in due course. These budgetary reports will include coverage of the quasi-fiscal activities undertaken by Sonangol on behalf of the government.

22. The BNA, as part of its modernization program, is continuing to implement the reform measures proposed in the IMF's Safeguards Assessment. The BNA has hired an international consultancy firm to help build capacity in the Internal Audit Office. The Board has appointed an investment committee tasked with providing ongoing oversight over reserve management operations and associated reporting. Formalization of investment guidelines for reserves management has been completed and the BNA's Internal Audit Office will commence issuance of semiannual reports on compliance with these guidelines in March 2011. Reconstitution of the BNA's Audit Board has been delayed for some time, but nomination of the new Audit Board members is now with the Minister of Finance for final approval, expected in the coming weeks. The BNA is committed to complete the external audit of its 2010 financial statements by June 2011 (structural benchmark). 


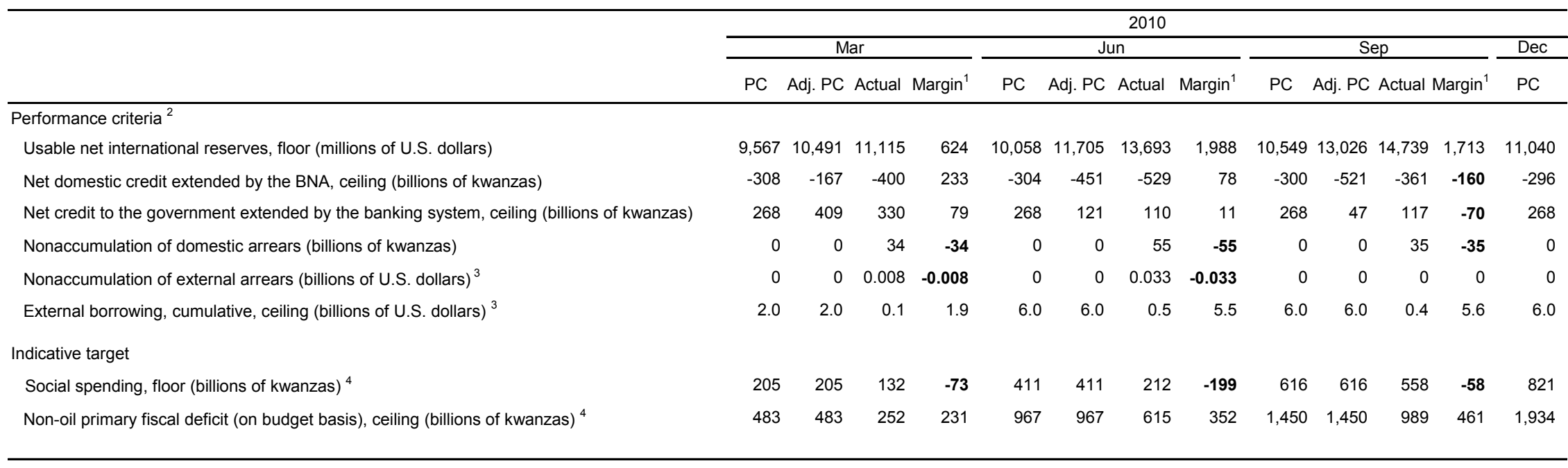

${ }^{1}$ A negative margin indicates that the PC or IT was missed.

${ }^{2}$ Performance criteria and indicative targets evaluated at program exchange rates.

${ }^{3}$ Continuous.

${ }^{4}$ Cumulative from January 1, 2010. 
Table 1b. Angola: Quantitative Performance Criteria (PC) and Indicative Targets (IT), 2011

\begin{tabular}{|c|c|c|c|c|}
\hline & \multicolumn{4}{|c|}{2011} \\
\hline & Mar & Jun & Sep & Dec \\
\hline & $\mathrm{PC}$ & $\mathrm{IT}$ & $\mathrm{PC}$ & Proj. \\
\hline \multicolumn{5}{|l|}{ Performance criteria ${ }^{1}$} \\
\hline Net international reserves, floor (millions of U.S. dollars) & 12,834 & 13,511 & 14,502 & 14,164 \\
\hline Net domestic credit extended by the BNA, ceiling (billions of kwanzas) & -518 & -564 & -644 & -529 \\
\hline Net credit to the government extended by the banking system, ceiling (billions of kwanzas) & 373 & 277 & 127 & 167 \\
\hline Accounts payable, ceiling (billions of kwanzas) & 100 & 100 & 100 & 100 \\
\hline Nonaccumulation of external arrears (billions of U.S. dollars) ${ }^{2}$ & 0 & 0 & 0 & 0 \\
\hline External borrowing, ceiling (billions of U.S. dollars) ${ }^{2}$ & 4.0 & 4.0 & 4.0 & 4.0 \\
\hline \multicolumn{5}{|l|}{ Indicative target } \\
\hline Social spending, floor (billions of kwanzas) ${ }^{3}$ & 185 & 424 & 630 & 997 \\
\hline Non-oil primary fiscal deficit (on budget basis), ceiling (billions of kwanzas) ${ }^{3}$ & 378 & 803 & 1,278 & 2,030 \\
\hline \multicolumn{5}{|l|}{ Memorandum items: } \\
\hline \multicolumn{5}{|l|}{ Program assumptions (billions of kwanzas) } \\
\hline Oil revenue & 635 & 1,294 & 1,980 & 2,691 \\
\hline External debt service by the central government & 29 & 66 & 93 & 185 \\
\hline Non-project medium and long-term government external borrowing & 0 & 0 & 0 & 0 \\
\hline
\end{tabular}

\footnotetext{
${ }^{1}$ Performance criteria and indicative targets evaluated at exchange rates defined in the TMU.

${ }^{2}$ Continuous.

${ }^{3}$ Cumulative from January 1, 2011.
} 
Table 2. Angola: Structural Reform Measures under the Stand-By Arrangement

\begin{tabular}{|c|c|c|c|}
\hline Objectives & Actions & Timing & Status \\
\hline \multicolumn{4}{|l|}{ Structural benchmarks } \\
\hline \multirow[t]{5}{*}{ Public finance management } & $\begin{array}{l}\text { Development of the project appraisal and monitoring framework, for } \\
\text { use in evaluating new projects on a pilot basis during the } 2012 \\
\text { budget process }\end{array}$ & September 2010 & Reset to May 2011 \\
\hline & $\begin{array}{l}\text { Auction of all new treasury securities based on fully market } \\
\text { determined interest rates }\end{array}$ & October 2010 & Met with delay, November 2010 \\
\hline & $\begin{array}{l}\text { Complete the settlement of all verified central government domestic } \\
\text { arrears incurred prior to end-December } 2010\end{array}$ & March 2011 & \\
\hline & $\begin{array}{l}\text { Submit for consideration to the National Assembly the new Public } \\
\text { Enterprise Law }\end{array}$ & March 2011 & \\
\hline & Cabinet approval of new debt management strategy & March 2011 & \\
\hline \multirow[t]{2}{*}{ Fiscal transparency } & $\begin{array}{l}\text { Publication of Sonangol's } 2009 \text { audited financial statements including } \\
\text { quasifiscal operations }\end{array}$ & November 2010 & Met with delay, December 2010 \\
\hline & $\begin{array}{l}\text { Begin quarterly publication of reports of central government budget } \\
\text { execution on the Ministry of Finance website, including coverage of } \\
\text { the expenditures undertaken by Sonangol on behalf of the central } \\
\text { government }\end{array}$ & June 2010 & Reset to June 2011 \\
\hline \multirow[t]{2}{*}{ Tax reform } & $\begin{array}{l}\text { Submission of the draft laws of the General Tax Code, the Code of } \\
\text { Tax Procedure and the Tax Collection Enforcement Code as well as } \\
\text { the draft tax code on Stamp Duty to the National Assembly }\end{array}$ & October 2010 & $\begin{array}{l}\text { Met, except for the draft tax code } \\
\text { on Stamp Duty }\end{array}$ \\
\hline & $\begin{array}{l}\text { Submission to the cabinet of a time-bound action plan for the } \\
\text { government's tax reform program }\end{array}$ & June 2011 & \\
\hline Financial sector stability & $\begin{array}{l}\text { Amend the regulation on capital adequacy to reflect the credit risk of } \\
\text { foreign currency loans }\end{array}$ & March 2011 & \\
\hline \multirow[t]{4}{*}{$\begin{array}{l}\text { Central bank safeguards } \\
\text { measures }\end{array}$} & $\begin{array}{l}\text { Appointment of an investment committee by the Board of Directors } \\
\text { of BNA to meet at least monthly to oversee reserves management } \\
\text { operations and reporting }\end{array}$ & May 2010 & Met with delay, November 2010 \\
\hline & $\begin{array}{l}\text { Formalization of investment guidelines for foreign reserves of the } \\
\text { BNA by the Board of Directors of BNA }\end{array}$ & July 2010 & Met with delay, December 2010 \\
\hline & $\begin{array}{l}\text { Issuance of semiannual reports by the Internal Audit Office of the } \\
\text { BNA to the Board on compliance with the foreign reserve investment } \\
\text { guidelines }\end{array}$ & September 2010 & Reset to March 2011 \\
\hline & $\begin{array}{l}\text { Reconstituting the Audit Board by: (i) replacing the member who has } \\
\text { a conflict of interest; (ii) adopting a Charter to define all statutory } \\
\text { responsibilities; and (iii) assuming oversight of the external audit and } \\
\text { financial reporting process. }\end{array}$ & June 2010 & Reset to January 2011 \\
\hline Central Bank transparency & Complete the 2010 audit of the BNA's financial statements & June 2011 & \\
\hline
\end{tabular}




\section{Attachment II}

\section{Technical Memorandum OF Understanding}

This memorandum sets out the understandings between the Angolan authorities and IMF staff regarding the definition of performance criteria and indicative targets, the associated adjustors, and the data reporting requirements for the duration of the Stand-By Arrangement. Where these criteria and targets are numeric, their unadjusted number values are stated in Table 1 of the Letter of Intent and Memorandum of Economic and Financial Policies. The values against which program compliance will be assessed will be adjusted up or down according to the adjustors specified in this Memorandum.

\section{A. Ceiling on the Overall Non-Oil Primary Deficit of the Central Government on a Budget Basis}

\section{Definition}

1. The central government will observe a ceiling on its Overall Non-Oil Primary Deficit on a Budget Basis. The observance of this ceiling is an indicative target. The overall Non-Oil Primary Deficit of the Central Government on a Budget Basis is defined as the cumulative balance since the start of the calendar year of the central government's expenditures, excluding interest payments and Sonangol's oil-related expenditure on behalf of government, and its non-oil revenues. It does not include the accumulation or clearance of arrears, payables and receivables.

\section{Data reporting requirements}

2. Data on the implementation of the budget compiled by the Treasury will be provided on a quarterly basis, to be submitted no later than eight weeks after the end of each reporting period.

3. The data to be reported are:

- $\quad$ Flows of (i) government revenue by category (including oil revenues received by the treasury); (ii) government expenditure, including current expenditure, domestic and external interest payments, Sonangol's oil-related expenditure on behalf of government, and capital expenditure, as well as all donor-financed expenditures; (iii) the net change in arrears, including the net change in the government's accounts payable and receivable; (iv) the gross clearance and gross accumulation of external arrears, including those resulting from agreements with the Paris Club creditors; (v) external loan receipts and principal payments; (vi) bank and nonbank financing, (vii) debt cancellation and debt swap operations; (viii) regularization bonds issued in 
settlement of payment arrears; (ix) any other revenue, expenditure, or financing not included above.

- $\quad$ Quarterly stocks of public domestic debt and external debt.

- $\quad$ The quarterly debt service projected for 2011 and annual debt service for 2012 through 2015.

\section{B. Ceiling on the Net Domestic Credit Extended by the Central Bank}

\section{Definition}

4. There will be a ceiling on the Net Domestic Credit Extended by the Central Bank. The observance of this ceiling is a performance criterion. Net Domestic Credit (NDC) Extended by the Central Bank is defined as the cumulative change, from the beginning of the calendaryear, of the stock of reserve money minus net foreign assets and other assets (net). Reserve money comprises bank reserves, cash in circulation, and deposits of the monetary institutions.

\section{Adjustors}

The ceiling for NDC will be adjusted upward by:

- The shortfall in oil revenues, net of Sonangol's oil-related expenditure on behalf of the central government, received by the Treasury relative to program assumptions.

- The external debt service by the central government in excess of program assumptions.

- The shortfall of non-project medium and long-term central government external borrowing relative to program assumptions.

The ceiling for NDC will be adjusted downward by:

- The oil revenues, net of Sonangol's oil-related expenditure on behalf of the central government, received by the Treasury in excess of the program assumptions.

- $\quad$ The shortfall in external debt service by the central government relative to program assumptions.

- The non-project medium and long-term central government external borrowing in excess of program assumptions

Those adjustors which are originally reported in dollars will be converted into Kwanza equivalents using the quarterly average exchange rate as reported in IFS.

\section{Data reporting requirement}

5. The monthly balance sheets of the central bank and the consolidated commercial banks will be transmitted on a monthly basis, with a maximum delay of three weeks. 


\section{Ceiling on Net Credit to the Central Government Extended by the Banking System (NCG)}

6. There will be a ceiling on the Net Credit to the Central Government by the Banking System. The observance of this ceiling is a performance criterion. Net credit to the central government from the banking system is defined as the net borrowing position of the main central government institutions vis-à-vis the banking system - that is, the stock of all outstanding claims on the central government (loans, advances and arrears), and all other government debt instruments, such as long-term government securities, held by the BNA and commercial banks less all deposits held by the central government with the BNA and with commercial banks.

\section{Adjustors}

The ceiling for NCG will be adjusted upward by:

- $\quad$ The shortfall in oil revenues, net of Sonangol's oil-related expenditure on behalf of government, received by the Treasury relative to program assumptions.

- The external debt service by the central government in excess of program assumptions.

- $\quad$ The shortfall of non-project medium and long-term central government external borrowing relative to program assumptions.

The ceiling for NCG will be adjusted downward by:

- The oil revenues, net of Sonangol's oil-related expenditure on behalf of government, received by the Treasury in excess of the program assumptions.

- The shortfall in external debt service by the central government relative to program assumptions.

- $\quad$ The non-project medium and long-term central government external borrowing in excess of program assumptions.

Those adjustors which are originally reported in dollars will be converted into Kwanza equivalents using the quarterly average exchange rate as reported in IFS.

\section{Data reporting requirement}

7. Data on the implementation of the budget compiled by the Ministry of Finance and Public Administration will be provided on a quarterly basis, to be submitted no later than six weeks after the end of each quarter, including (i) government domestic revenue by category; (ii) external budget support grants; (iii) government expenditure, including primary current expenditure, domestic and external interest payments, and capital expenditure, including domestically and budget support financed capital expenditure and estimates of externally project financed capital expenditure; (iv) the gross payment and gross accumulation 
of domestic accounts payable; (v) the gross payment and gross accumulation of domestic payments arrears; (vi) external loan receipts and principal payments; (vii) external arrears payments and accumulation; (viii) bank and nonbank financing; (ix) the stock of regularization bonds held by commercial banks; (x) privatization and land sale receipts; and (xi) any other revenue, expenditure, or financing not included above.

8. For the purposes of this memorandum, privatization and land proceeds will be understood to mean all monies received by the government from the sale or concession of a public company, organization, or facility to a private company or companies, organization(s), or individual(s), as well as any proceeds generated from the sale of government land and the liquidation of a public company, less restructuring costs.

\section{Floor on the Net International Reserves of the Central Bank}

\section{Definition}

9. Net international reserves (NIR) of the National Bank of Angola (BNA) are defined as the dollar value of gross foreign assets of the BNA minus gross foreign liabilities of the BNA with maturity of less than one year and all of Angola's credit outstanding from the Fund. Non-dollar denominated foreign assets and liabilities will be converted into dollars at the IFS exchange rates as of December 31 of the previous year. Data will be provided by the BNA to the Fund with a lag of not more than one week after the test date.

- $\quad$ Gross foreign assets are defined as readily available claims on nonresidents denominated in foreign convertible currencies. They include the BNA's holdings of monetary gold, SDRs, foreign currency cash, foreign currency securities, deposits abroad, and the country's reserve position at the Fund. Excluded from reserve assets are any assets that are pledged, collateralized, or otherwise encumbered, claims on residents, claims in foreign exchange arising from derivatives in foreign currencies visà-vis domestic currency (such as futures, forwards, swaps, and options), precious metals other than gold, assets in nonconvertible currencies, and illiquid assets. As of December 31, 2009, foreign reserve assets thus defined amounted to US\$10.888 billion.

- Gross foreign liabilities are defined as all short-term foreign exchange liabilities of the BNA to nonresidents, including commitments to sell foreign exchange arising from derivatives (such as futures, forwards, swaps, and options) and all credit outstanding from the Fund. As of December 31, 2009, reserve liabilities thus defined amounted to US\$0.365 million.

\section{Adjustors}

The floor on NIR will be adjusted upward by: 
- The oil revenues, net of Sonangol's oil-related expenditure on behalf of government, received by the Treasury in excess of the program assumptions.

- $\quad$ The shortfall in external debt service by the central government relative to program assumptions.

- $\quad$ The non-project medium- and long-term central government external borrowing in excess of program assumptions.

The floor on NIR will be adjusted downward by:

- $\quad$ The shortfall in oil revenues, net of Sonangol's oil-related expenditure on behalf of government, by the Treasury relative to program assumptions.

- $\quad$ The external debt service by the central government in excess of program assumptions.

- $\quad$ The shortfall of non-project medium and long-term central government external borrowing relative to program assumptions.

The adjustors will be applied only to the extent that the floor on the stock of NIR remains at or above US\$6 billion. Those adjustors originally reported in Kwanza (or in any currency other than the dollar) will be converted into dollar equivalents using the average quarterly exchange rates as reported in IFS.

\section{Data reporting requirement}

10. A table prepared by the central bank will be transmitted weekly, with a maximum delay of one week, with the daily values of the stock of NIR and the decomposition of the daily variation of the NIR stock into foreign exchange sales to, and purchases from, the government, banks, nonbanks, and SDR purchases from the IMF, interest accrual, and valuation changes. The table will also indicate any off-balance sheet position denominated or payable in foreign currency by the central bank. Data on exports and imports, including volume and prices and compiled by the Customs and central bank will be transmitted on a quarterly basis within six weeks after the end of each quarter. A preliminary quarterly balance of payments (including non-project medium and long-term central government external borrowing), compiled by the central bank, will be forwarded within six weeks after the end of each quarter.

\section{E. Ceiling on External Debt Contracted or Guaranteed by the Central Government}

\section{Definition}

11. For program purposes, the definition of debt is set out in Executive Board Decision No. 230-(79/140), Point 9, as revised on August 31, 2009 (Decision No. 14416-(09/91)) (see Annex I). 
12. There will be a ceiling on debt contracted or guaranteed by the central government and the BNA with nonresidents. The ceiling is specified in Table 1 as a continuous performance criterion. The ceiling applies to debt and commitments contracted or guaranteed for which value has not yet been received. This applies to private debt for which official guarantees have been extended and which, therefore, constitute a contingent liability of the public sector. The observance of this ceiling is a performance criterion. Sonangol and other SOEs will not contract external debt on behalf of the central government. For program purposes, all debt denominated in currencies other than the U.S. dollar will be converted into U.S. dollars at program exchange rates.

13. Excluded from the ceiling are (i) the use of Fund resources (ii) debts incurred to restructure, refinance, or prepay existing debt. These are further specified in Table 1 of the Memorandum of Economic and Financial Policies and related program documents.

14. For program purposes, the guarantee of a debt arises from any explicit legal obligation of the public sector to service a loan in the event of nonpayment by the recipient (involving payments in cash or in kind), or indirectly through any other obligation of the public sector to finance partially or in full any shortfall incurred by the loan recipient.

\section{Data reporting requirements}

15. The government will consult with Fund staff before assuming any liabilities in circumstances where they are uncertain whether the instrument in question falls under the performance criterion. A debt-by-debt accounting of all new debt contracted or guaranteed by the central government, including the original debt documentation, details on debt service obligations, as well as all relevant supporting materials, will be transmitted within six weeks of the end of each quarter. The data on outstanding stock of undisbursed non-concessional debt as well as outstanding stock of unused credit lines from framework agreements will be reported to Fund staff at the end of each quarter. In addition, during the preparation of the budget, the full breakdown of projected disbursements for the budget from old project debt contracts and new project debt contracts will be provided to Fund staff.

\section{F. Ceiling on the Net Accumulation of Domestic Accounts Payable}

\section{Definition}

16. There will be a ceiling of Kwanza 100 billion on the net accumulation of domestic accounts payable. The net accumulation of accounts payable will be measured as the change in accounts payable reported between January 1, 2011 and each program test date. This measurement will exclude all operations related to payments originating before 2010, which are considered clearance of "arrears" in a strict sense and will be reported separately from other changes in payables. 


\section{Data reporting requirement}

17. The Treasury will submit on a quarterly basis a detailed table of the gross and net change in the domestic accounts payable of the central government. This table will clearly identify those operations which represent the clearance of payables dating to before 2010, that is, "arrears" clearance operations in a strict sense. A similar table pertaining to receivables will also be provided. The data are to be provided within six weeks after the end of the quarter.

\section{G. Non-accumulation of External Payments Arrears}

\section{Definition}

18. The central Government may not accumulate external payments arrears. This obligation is a continuous performance criterion. External arrears are defined as total external debt-service obligations of the government and the central bank that have not been paid by the time they are due, except where agreements between the government and creditors explicitly provide for a grace period after such obligations falling due, in which case the obligation will be in arrears if not paid within the grace period. Obligations in negotiation with creditors are considered arrears until an agreement is legally in effect.

\section{Data reporting requirements}

19. Data on external arrears accumulation, clearance, and rescheduling will be transmitted weekly by the BNA at most one week after the fact.

\section{H. Floor on the Central Government Social Expenditure}

\section{Definition}

20. There will be a floor on the Central Government Social Expenditure. The observance of this floor is an indicative target. Social expenditure comprises spending on the following sectors: education, health, rural development, and social affairs. The floor will be set at 30 percent of programmed total expenditures during the program period.

\section{Data reporting requirements}

Data on Social Spending will be compiled by the Treasury and will be provided on a quarterly basis, to be submitted no later than six weeks after the end of each reporting period. 


\section{AnNeX I. \\ Guidelines on Performance Criteria With ResPect to Foreign Debt}

Excerpt from Executive Board Decision No. 6230-(79/140), as revised on August 31, 2009 (Decision No. 14416-(09/91)).

9. (a) For the purpose of this guideline, the term "debt" will be understood to mean a current, i.e., not contingent, liability, created under a contractual arrangement through the provision of value in the form of assets (including currency) or services, and which requires the obligor to make one or more payments in the form of assets (including currency) or services, at some future point(s) in time; these payments will discharge the principal and/or interest liabilities incurred under the contract. Debts can take a number of forms, the primary ones being as follows:

(i) loans, i.e., advances of money to the obligor by the lender made on the basis of an undertaking that the obligor will repay the funds in the future (including deposits, bonds, debentures, commercial loans and buyers' credits)and temporary exchanges of assets that are equivalent to fully collateralized loans under which the obligor is required to repay the funds, and usually pay interest, by repurchasing the collateral from the buyer in the future (such as repurchase agreements and official swap arrangements);

(ii) suppliers' credits, i.e., contracts where the supplier permits the obligor to defer payments until sometime after the date on which the goods are delivered or services are provided; and

(iii) leases, i.e., arrangements under which property is provided which the lessee has the right to use for one or more specified period(s) of time that are usually shorter than the total expected service life of the property, while the lessor retains the title to the property. For the purpose of the guideline, the debt is the present value (at the inception of the lease) of all lease payments expected to be made during the period of the agreement excluding those payments that cover the operation, repair or maintenance of the property. (b) Under the definition of debt set out in point 9 (a) above, arrears, penalties, and judicially awarded damages arising from the failure to make payment under a contractual obligation that constitutes debt are debt. Failure to make payment on an obligation that is not considered debt under this definition (e.g., payment on delivery) will not give rise to debt. 


\section{ANNEX I. ANgOla: Relations With THE Fund}

(As of December 31, 2010)

I. Membership Status: Joined September 19, 1989; Article XIV

II. General Resources Account:

SDR Million

Percent

Quota

286.30

100.00

Fund holdings of currency

630.01

220.05

III. SDR Department:

SDR Million

Percent

Net cumulative allocation

273.01

100.00

Holdings

269.92

98.87

IV. Outstanding Purchases and Loans:

SDR Million

Percent

Stand-By Arrangements

343.56

120.00

V. Latest Financial Arrangements

\begin{tabular}{llrrr}
\hline Type & $\begin{array}{l}\text { Date of } \\
\text { Arrangement }\end{array}$ & $\begin{array}{r}\text { Expiration } \\
\text { Date } \\
\text { (SDR Million) }\end{array}$ & $\begin{array}{r}\text { Amount } \\
\text { Approved } \\
\text { (SDR Million) }\end{array}$ & $\begin{array}{r}\text { Amount } \\
\text { Drawn }\end{array}$ \\
\hline $\begin{array}{l}\text { Stand-By- } \\
\text { Arrangement }\end{array}$ & Nov. 23, 2009 & Feb. 22, 2012 & 858.90 & 343.56 \\
\hline
\end{tabular}

VI. Projected Payments to Fund: (SDR Million)

\begin{tabular}{lrrrrr}
\hline & \multicolumn{5}{c}{ Forthcoming } \\
\hline & 2010 & 2011 & 2012 & 2013 & 2014 \\
\hline Principal & & & & 143.15 & 171.78 \\
Charges/Interest & 2.20 & 4.55 & 4.55 & 4.02 & 1.94 \\
Total & 2.20 & 4.55 & 4.55 & 147.17 & 173.72 \\
\hline
\end{tabular}

VII. Implementation of HIPC Initiative: Not applicable

VIII. Safeguards Assessments: The first-time safeguards assessment of the National Bank of Angola (BNA) found that the central bank is subject to annual external audits by a reputable audit firm and has taken steps to address the audit qualifications. The assessment confirmed, however, weak governance and transparency practices at the BNA, including lack of timely publication of annual financial statements. The assessment also made recommendations to enhance the legal framework and independence of the central bank, and to strengthen the control framework in the reserves management and internal audit areas.

IX. Exchange Arrangements: Angola's de facto exchange arrangement has been classified as "other managed" since October 2009. The Banco Nacional de Angola (BNA) intervenes actively in the foreign exchange market in order to sterilize foreign currency inflows in the form of taxes paid by oil companies. Auctions were temporarily suspended from April 20 to October 1, 2009 leading to the establishment of a formal peg. Since the resumption of auctions, 
the kwanza has depreciated. However, the authorities maintain strong control on the exchange rate, which is the main anchor for the monetary policy. The BNA publishes a daily reference rate, which is computed as the transaction-weighted average of the previous day's rates negotiated with commercial banks. Banks and exchange bureaus may deal among themselves and with their customers at freely negotiated rates.

Angola continues to avail itself of the transitional arrangements under the provisions of Article XIV, Section 2 and maintains two exchange measures, namely, (i) limits on the availability of foreign exchange for invisible transactions, such as travel, medical, or educational allowances and (ii) limits on unrequited transfers to foreign-based individuals and institutions. In addition, Angola maintains two exchange restrictions resulting from: (i) limits on the remittances of dividends and profits from foreign investments that do not exceed US $\$ 100,000$, and (ii) the discriminatory application of the 0.015 percent stamp tax on foreign exchange operations that are subject to approval under Article VIII, Section 2(a). Angola maintains two multiple currency practices (i) arising from the Dutch foreign exchange auction, and (ii) the discriminatory application of the 0.015 stamp tax on foreign exchange operations that are subject to approval under Article VIII, Section 3.

X. Article IV Consultation: Angola is on the 24-month cycle for program countries. The next Article IV Consultation is scheduled to be completed in conjunction with the $5^{\text {th }}$ Review under the Stand-By Arrangement.

XI. Technical Assistance: Angola has received substantial technical assistance since it joined the Fund. Technical assistance activities since 2005 are listed below:

\section{Monetary and Capital Markets (MCM)}

Monetary operations and liquidity management, foreign exchange operations, and banking supervision Foreign exchange auction system Framework on liquidity management Inflation analysis and forecasting Debt management and market development

\section{Fiscal Affairs Department (FAD)}

Tax administration workshop

Fiscal ROSC mission

Tax reform (mission participation)

\section{Statistics Department (STA)}

External sector statistics Government finance statistics

External sector statistics

Balance of payment statistics

\section{Legal (LEG)/Monetary and Capital Markets (MCM)}

Review of exchange arrangements and restrictions

\section{Year of Delivery}

2004-06

2009

2010

2010

2010

2005

2006

2010

2009

2006

2009

2010

XII. Resident Representative: A Resident Representative is expected to be appointed early in 2011. 
AnNex II-Angola: Joint IMF-World Bank Management ACTION Plan

\section{Implementation Matrix}

\begin{tabular}{|c|c|c|c|}
\hline Title & Products & $\begin{array}{l}\text { Provisional } \\
\text { Timing of } \\
\text { Missions }\end{array}$ & $\begin{array}{l}\text { Expected } \\
\text { Delivery Date }\end{array}$ \\
\hline \multicolumn{4}{|c|}{ A. Mutual Information on Relevant Work Programs } \\
\hline \multirow[t]{8}{*}{$\begin{array}{l}\text { Bank work } \\
\text { program }\end{array}$} & $\begin{array}{l}\text { Implementing current Interim Strategy Note } \\
\text { and preparation of a new Full—fledged } \\
\text { Country Assistance Strategy. }\end{array}$ & & September 2010 \\
\hline & $\begin{array}{l}\text { Small Holder Agriculture Development } \\
\text { Project_effectiveness }\end{array}$ & & May 2010 \\
\hline & $\begin{array}{l}\text { Water Sector Institutional Development } \\
\text { Project—effectiveness }\end{array}$ & & May 2010 \\
\hline & $\begin{array}{l}\text { Social Fund Project for Municipal } \\
\text { Development and Local Delivery of Public } \\
\text { Goods (FAS 4)-Effectiveness }\end{array}$ & & June 2010 \\
\hline & Health Project—Approval & & June 2010 \\
\hline & $\begin{array}{l}\text { Public Investment Management Analysis and } \\
\text { Prioritizing Public Investment Policy Note }\end{array}$ & & May 2010 \\
\hline & Education Country Status Report & & December 2010 \\
\hline & Capacity Building Strategy & & May 2010 \\
\hline \multirow{3}{*}{$\begin{array}{l}\text { IMF work } \\
\text { program in next } \\
12 \text { months }\end{array}$} & Staff visit & & March 2011 \\
\hline & Article IV consultation/Fifth review of SBA & & June 2011 \\
\hline & Sixth review of the SBA & & December 2011 \\
\hline \multicolumn{4}{|c|}{ B. Request for Work Program Inputs } \\
\hline $\begin{array}{l}\text { Fund request to } \\
\text { Bank }\end{array}$ & $\begin{array}{l}\text { TA on prioritizing capital spending } \\
\text { (including a criteria to determine which } \\
\text { projects to include in the government's } \\
\text { public investment program, including cost- } \\
\text { benefit analysis) }\end{array}$ & & TBC \\
\hline \multicolumn{4}{|c|}{ C. Agreement on Joint Programs and Missions } \\
\hline $\begin{array}{l}\text { Bank request to } \\
\text { Fund }\end{array}$ & $\begin{array}{l}\text { Continuous dialogue on economic forecast } \\
\text { and macroeconomic modeling issues for } \\
\text { Angola }\end{array}$ & & Continuous \\
\hline
\end{tabular}




\begin{tabular}{|l|l|l|l|}
\hline Title & Products & $\begin{array}{l}\text { Provisional } \\
\text { Timing of } \\
\text { Missions }\end{array}$ & $\begin{array}{l}\text { Expected } \\
\text { Delivery Date }\end{array}$ \\
\hline $\begin{array}{l}\text { Joint products in } \\
\text { next 12 months }\end{array}$ & \begin{tabular}{l} 
Financial Stability Assessment Program \\
\cline { 2 - 4 }
\end{tabular} & $\begin{array}{l}\text { Better monitoring of public enterprises } \\
\text { (including to reduce fiscal risks) }\end{array}$ & June 2011 \\
\cline { 2 - 5 } & $\begin{array}{l}\text { Exchange of information and mutual } \\
\text { consultations on macroeconomic } \\
\text { developments }\end{array}$ & Continuous \\
\hline
\end{tabular}




\section{Angola: Statistical IsSUeS}

1. Data provision has shortcomings, but is broadly adequate for surveillance and program performance. There are major concerns about data quality and timeliness and efforts are underway to strengthen the statistical base, including through technical assistance from the Fund and the World Bank. The authorities are committed to using the General Data Dissemination System (GDDS) to improve the statistical system. Angola has participated in the GDDS project for Lusophone African countries, and has received technical assistance in this area. Angola started participating in the GDDS in October 2003 and metadata were posted on the IMF's Dissemination Standards Bulletin Board. The metadata need to be updated.

2. The only regular statistical publication is the quarterly National Bank of Angola (BNA) statistical bulletin, which is often published with a considerable delay. Data postings on the government website (www.minfin.gv.ao), including revenues from the oil sector, have not been as timely as recommended in the GDDS. Government accounts are released when the annual budget is approved.

\section{National accounts and price statistics}

3. Official GDP estimates are produced annually and generally only by sector, with no disaggregation by industry and the public sector is under-represented. Annual GDP at constant prices is estimated using 2002 prices. There are no estimates of GDP by expenditure. Apart from oil production, sectoral data are calculated using indicators with weights based on incomplete surveys conducted in 2001 or earlier. A lack of statistical offices in the provinces significantly limits data coverage. The CPI is based on a basket of goods and services for which prices are collected in Luanda. The geographical coverage of price collection was extended to five more provinces and an unofficial quarterly index has been compiled commencing in 2005, but a September 2006 STA CPI Mission did not regard these data as sufficiently reliable for publication. The CPI weights were revised in January 2002 based on a household survey conducted in 2001. CPI data are produced monthly, normally with a lag of two weeks. There are no wholesale or producer price indices.

\section{Monetary and financial statistics}

4. Data for the depository corporation survey and the balance sheet of the central bank are timely but based on old report forms. There have been deficiencies in the reporting of foreign exchange reserves and concerns about the quality and timeliness of reports from some commercial banks. A March 2006 STA mission assisted the BNA in starting compilation of monthly monetary statistics using the new standardized report forms (SRFs). The mission made several recommendations for improving monetary statistics and finalizing the SRFs, including the classification of bank holdings of treasury bills and bonds and central bank bills, and the valuation of foreign currency-denominated accounts. Further priorities were to improve accounting procedures in state-owned banks and strengthen the BNA's internal controls, particularly for external transactions. Implementation of the mission's recommendations has been incomplete, although there was progress in preparing a new plan of accounts for the other depository corporations, which is expected to be implemented soon. 
5. A May 2007 follow-up mission assisted the BNA in finalizing the SRFs for the central bank, but further work is needed to finalize the SRF for the other depository corporations. The mission also focused on the intersectoral consistency of the monetary and the government finance and balance of payments statistics, and provided on-the-job training. Once the link between the SRFs and the new accounting data of the other depository corporations is finalized, the SRFs will be used to derive an integrated monetary database to meet the needs of the BNA, as well as AFR and STA.

\section{Government finance statistics}

6. The timeliness and quality of government finance statistics needs to be improved. Budget execution reports reflect liabilities for tax payments as estimated in the budget (budget basis), rather than revenues collected (cash basis); and expenditures reflect only expenditures on a cash basis rather than expenditure on a commitment basis. Data from the SIGFE management information system are still limited in coverage and reliability, and subject to revisions. Monthly government accounts rely to an unusually large extent on estimates based on the budget rather than on actual execution figures. The MoF does not report a significant number of series for government finance data for publication in the GFS Yearbook or in International Financial Statistics.

\section{External sector statistics}

7. The balance of payments and international investment position are compiled in line with the recommendations of the fifth edition of the IMF's Balance of Payments Manual. These statistics are compiled and disseminated annually, with a lag of nine months after the reference period. A technical assistance mission on external sector statistics was conducted in July 2010. It noted that few of the recommendations made by the previous missions had been implemented and that little progress had been made in strengthening the compilation framework, the technical units are understaffed and there are problems of non-compliance with data reporting requirements by resident enterprises. A thorough review of the balance of payments and IIP for 2008 and 2009 was conducted. Progress was noticed, in comparison to the previous mission, regarding the methodological soundness of classification of balance of payments transactions. Nonetheless, some inconsistencies have been found, especially regarding the classification of transactions involving arrears and SDRs. The IIP showed important inconsistencies with the balance of payments and the external debt statement. Coverage and timeliness of source data remain a major shortcoming. The development of the BNA's International Transactions Reporting System (ITRS), known as SIOBE, was halted due both to lack of staff and the uncertainty regarding its replacement by a similar ITRS being developed by the BNA.

8. In addition, the mission also noted that the continued improvement in the quality of statistics depends on: (1) an increase in the rate of response to the surveys, including the adoption of administrative measures to curb noncompliance with reporting requirements; (2) implementation of tools and mechanisms for the organization, analysis and validation of ITRS data; (3) compliance with commitments in the agreements signed with the National Statistics Institute, and the MoF for access to their databases; and (4) integration of more data sources. 


\section{Angola: Table of Common Indicators Required for Surveillance}

(As of December 15, 2010)

\begin{tabular}{|c|c|c|c|c|c|}
\hline & $\begin{array}{c}\text { Date of } \\
\text { Latest } \\
\text { Observation }\end{array}$ & $\begin{array}{l}\text { Date } \\
\text { Received }\end{array}$ & $\begin{array}{c}\text { Data } \\
\text { Frequency }\end{array}$ & $\begin{array}{l}\text { Reporting } \\
\text { Frequency }^{5}\end{array}$ & $\begin{array}{l}\text { Publication } \\
\text { Frequency }^{5}\end{array}$ \\
\hline Exchange rates & Dec. 2010 & Dec. 2010 & $\mathrm{D}$ & $\mathrm{D}$ & $\mathrm{D}$ \\
\hline $\begin{array}{l}\text { International reserve assets and } \\
\text { reserve liabilities of the monetary } \\
\text { authorities }^{1}\end{array}$ & Nov. 2010 & Dec. 2010 & W & M & $\mathrm{M}$ \\
\hline Reserve/base money & Nov. 2010 & Dec. 2010 & W & M & $M$ \\
\hline Broad money & Oct. 2010 & Dec. 2010 & M & M & M \\
\hline Central Bank balance sheet & Nov. 2010 & Dec. 2010 & W & M & M \\
\hline $\begin{array}{l}\text { Consolidated balance sheet of the } \\
\text { banking system }\end{array}$ & Oct. 2010 & Dec. 2010 & M & $\mathrm{M}$ & $\mathrm{M}$ \\
\hline Interest rates & Sept. 2010 & Dec. 2010 & $\mathrm{M}$ & M & $\mathrm{M}$ \\
\hline Consumer Price Index & Oct. 2010 & Dec. 2010 & $M$ & M & $M$ \\
\hline $\begin{array}{l}\text { Revenue, expenditure, balance and } \\
\text { composition of financing }^{2}-\text { General } \\
\text { Government }^{3}\end{array}$ & Sept. 2010 & Dec. 2010 & $Q$ & $Q$ & $Q$ \\
\hline $\begin{array}{l}\text { Revenue, expenditure, balance and } \\
\text { composition of financing }{ }^{2}-\text { Central } \\
\text { Government }\end{array}$ & Sept. 2010 & Dec. 2010 & Q & Q & $Q$ \\
\hline $\begin{array}{l}\text { Central Government and Central } \\
\text { Government-guaranteed debt }\end{array}$ & Sept. 2010 & Dec. 2010 & $Q$ & $Q$ & $Q$ \\
\hline External current account balance & 2009 & June 2010 & $A$ & A & $A$ \\
\hline $\begin{array}{l}\text { Exports and imports of goods and } \\
\text { services }\end{array}$ & 2009 & June 2010 & $A$ & $A$ & A \\
\hline GDP/GNP & 2009 & June 2010 & $A$ & $A$ & A \\
\hline Gross external debt & Sept. 2010 & Nov. 2010 & M & $Q$ & M \\
\hline International Investment Position ${ }^{6}$ & 2009 & Jun. 2010 & $A$ & I & $A$ \\
\hline
\end{tabular}

${ }^{1}$ Includes reserve assets pledged or otherwise encumbered as well as net derivative positions.

${ }^{2}$ Foreign, domestic bank, and domestic nonbank financing.

${ }^{3}$ The general government consists of the central government (budgetary funds, extra budgetary funds, and social security funds) and state and local governments.

${ }^{4}$ Including currency and maturity composition.

${ }^{5}$ Daily (D), weekly (W), monthly (M), quarterly (Q), annually (A), irregular (I), not available (NA).

${ }^{6}$ Includes external gross financial asset and liability positions vis-à-vis nonresidents. 


\section{Statement by the IMF Staff Representative on Angola}

January 24, 2011

This statement is intended to update Executive Directors on program-related developments in Angola since the issuance of the staff report for the Fourth Review under the Stand-By Arrangement, Request for Waivers of Nonobservance of Performance Criteria, Request for Waivers of Applicability of Performance Criteria, and Request for Modification of Performance Criteria. The new information does not alter the thrust of the staff appraisal.

1. Preliminary end-December data indicate that gross international reserves of the National Bank of Angola (BNA) increased by some \$2 billion in the last quarter, with the bulk of the increase occurring in the second half of December. Sizeable payments from the oil sector to the government, the timing of which can fluctuate, are the likely source for this unanticipated surge in reserves.

2. The impact of the stronger-than-expected reserve increase on performance in relation to end-December performance criteria is uncertain: the performance criteria on net international reserves, net domestic credit of the BNA, and central government borrowing from the banking system all include an adjustor for deviations of budgetary oil revenues from program assumptions, and the magnitude of this adjustor is not yet known.

3. The government continues to clear arrears accumulated during 2008-09. The authorities report that they paid off an additional $\$ 0.9$ billion of these arrears during the final months of the year, supplementary to the $\$ 2.7$ billion cleared during the third quarter.

4. The authorities expect to pay off the residual amount of accounts payable that were outstanding as of end-September within the next week; they had hoped to complete these payments by January $7_{\text {th. }}$.

5. Consumer price inflation (12-month) in December was 15.3 percent, down from a peak of 16.1 percent in October. The decline was in line with staff expectations. 
Press Release No. 11/18

FOR IMMEDIATE RELEASE

January 24, 2011

International Monetary Fund

Washington, D.C. 20431, USA

\section{IMF Executive Board Completes Fourth Review Under Stand-By Arrangement with Angola and Approves US\$178.2 Million Disbursement}

The Executive Board of the International Monetary Fund (IMF) today completed the fourth review of Angola's economic performance under a program supported by the Stand-By Arrangement. The Board's decision enables the immediate disbursement of an amount of SDR 114.52 million (about US\$178.2 million), bringing total disbursements under the arrangement to Angola to SDR 687.12 million (about US\$1.07 billion).

In completing the program review, the Executive Board approved waivers for the nonobservance of the end-December 2010 performance criteria concerning the ceilings on arrears accumulation, on central bank credit extended, and on banking system credit to government and. The Executive Board also approved the modification of the performance criteria relating to domestic arrears and to central bank credit.

At the conclusion of the Executive Board's discussion on Angola, Mr. Naoyuki Shinohara, Deputy Managing Director and Acting Chair, stated:

“The Angolan authorities' economic and financial program achieved significant progress towards macroeconomic stability as a result of the solid implementation of key program measures, supported by a rebound in oil prices. Foreign reserves are being rebuilt and the fiscal position is improving, aided by expenditure adjustment.

"Spending restraint and recovering oil prices created space for clearance of much of the domestic payments arrears built up in 2008-09. The authorities plan to settle the remainder of these arrears by end-March 2011.

"The 2011 budget balances the need to rebuild reserves with the need to boost capital outlays, which were cut significantly as part of the fiscal adjustment in 2009-10. The effective implementation of quarterly financing plans for line ministries, matching spending commitments with available financial resources, will be a welcome development. 
"Monetary policy is appropriately geared to gradually reducing inflation towards single-digit levels. With eased pressures in the currency market, the central bank should rely exclusively on market-based measures to manage exchange rate movements.

"Looking ahead, the authorities' intention to develop fiscal policy guidelines that would smooth spending levels over the oil price cycle and prevent arrears accumulation will be useful. The multi-year overhaul of the non-oil tax system will also contribute to ensuring fiscal stability over the medium-term.

"Improving transparency in the public sector is a critical goal; publication of externallyaudited financial statements of public entities is an essential measure in this regard. The central bank's implementation of its organizational reform agenda will strengthen its internal governance structures," Mr. Shinohara said. 


\title{
Statement by Mr. Majoro, Executive Director for Angola
}

\author{
January 24, 2011
}

\section{Introduction}

My Angolan authorities would like to convey their gratitude to staff for the constructive policy dialogue during the fourth review under the Stand-By Arrangement (SBA). They also wish to extend gratitude to Fund Management and the Board for their support and valuable policy advice. My authorities agree with the thrust of the staff analysis and report. They request the completion of the fourth review under the SBA, waivers for the nonobservance and applicability, and modification of performance criteria.

Recent economic development and program implementation

Six years into post-war reconstruction, the country was severely hit by the global economic downturn that adversely affected economic activity and exchange rates, and has exacerbated delays in payments to construction firms and other government suppliers. Notwithstanding this setback, the economy performed well under the authorities' stabilization program supported by the SBA. According to the authorities, the 2010 real GDP growth is estimated to have recovered from 2.7 percent in 2009 to 6.7 percent, supported by rising oil output and prices, restrained fiscal spending and uninterrupted consolidation of the non-mineral sector. Reduced fuel price subsidy and rising food prices during the last quarter of 2010 could push inflation expectations upwards.

The medium-term outlook is positive given the authorities' decision to pursue its pre-crisis development agenda. To that end, the authorities intend to advance implementation of electricity and water supply projects, continue to implement the ambitious housing program, reduce regional disparities and address youth unemployment. The authorities are mindful of the significant role played by the mineral sector, though buoyant agricultural, energy and construction sectors, as well as a favorable environment in trade and services are set to emerge rapidly as new growth drivers. Also, in 2012 new oil fields and a large Liquefied Natural Gas (LNG) plant will increase the country's growth potential and its ability to pursue relentlessly its short to medium term development program.

The program is broadly on track. All structural benchmarks and quantitative performance criteria set for end-September 2010 were met, with the exception of three performance criteria. The PC on the non-accumulation of new arrears proved to be ambitious, given the mechanics of the government's payments system and the inability of government to track the PC as defined. The ceiling on net domestic credit extended by the BNA was missed in large part as a reflection of the impact of settlement of domestic arrears and domestic debt. The ceiling on 
banking system credit to the government was missed by a modest margin, stemming from large cash payments made in the third quarter to clear the 2008-09 payments arrears.

Future Policy Outlook

\section{The 2011 Budget}

The 2010 budget was concluded under the new budget law that reinforces best practice in fiscal management. Accordingly, and with the recovery from the global economic crisis, public finance performance resulted in a budget surplus reflecting the recovery in government oil revenue and tight spending restraints. The 2011 budget focuses on reestablishing external reserves, settling the remainder of arrears and increasing capital spending in key social and economic infrastructures.

Given the uncertainties surrounding the global economy, the authorities have adopted a cautious stance. Spending on social programs is estimated to reach 31.5 percent of total expenditure, broadly in line with the program. My Angolan authorities are aware of the fiscal challenges ahead and intend to address them by improving public finance management which include the publication of quarterly budget execution reports, broadening the tax base, tightening spending controls, reducing fuel subsidies, and creating a solid and autonomous revenue authority. In order to tighten budget expenditure and avoid extra-budgetary spending, they will implement in 2011 a quarterly spending program for each line ministry that limits outlays to a ceiling agreed in advance with the budgetary directorate. The authorities also intend to clear most of the domestic arrears by end-March 2011.

\section{Monetary policy}

My authorities are vigorously pursuing restoration of market confidence, achieving international reserves adequacy, controlling liquidity, and stabilizing the exchange rate. In this regard, the Banco Nacional de Angola will continue focusing its market intervention in the issuance of central bank bills through open-market operations as one of the main mechanisms to manage liquidity. The Bank will continue to use reserve requirements and the policy rate as instruments to guide lending activities of the commercial banks. The authorities are mindful of the risks of inflation associated with commodity price increases and, in this regard, will continue their efforts to take necessary measures to lower inflation from the current double digits to the targeted single digits.

\section{Financial sector stability}

The limited exposure of the Angolan banking system to international financial markets has lessened the impact of global financial instability. The authorities intend to limit central bank intervention to finance the spending through the introduction of longer term Treasury bills (128 and 364 day maturities). 
Banking supervision is also seen as vital and, in this regard, BNA will implement in the first quarter of 2011 the Basel II prudential requirements, adopt the regulatory framework against money laundering and terrorism financing, as well as establish a consumer credit bureau. The authorities are prepared to work with staff in the context of the upcoming FSAP, to design and implement a framework to further strengthen the Angolan financial sector.

Having obtained a B+ sovereign rating from Moody's, Fitch and Standard and Poor's rating agencies in mid 2010, my Angolan authorities are keen to raise financing from the international credit and bond markets to address the infrastructural deficit and key poverty-alleviation programs.

\section{External sector}

Exports, in 2010 rose due to an increase in oil production and oil prices and will likely rise further in 2011 and 2012 as the LNG project comes on stream. Oil production is forecast to remain stable from then onwards, owing to slowing output growth and moderating prices in the commodity markets. My Angolan authorities' project in 2011 a current account surplus for the first time since the late 1990s due to the expanded activity in the oil sector and exports that will likely offset imports for the infrastructure projects.

\section{Reform agenda}

My Angolan authorities are committed to implement the ongoing 2009-12 national development plan aimed at strengthening business climate and reinforcing institutional and judicial systems. These reforms are set to bolster investor confidence and spur private investment in the non-oil sector. In addition to initiating the FSAP in March 2011 with Fund's TA, my authorities are also making efforts to reform public financial management and the domestic tax regime, as well as the development of a sovereign wealth fund to manage budgetary savings for future generations.

My authorities continue to strengthen the capacity of the newly-established debt management unit and will adopt the legal framework needed to manage public private partnerships (PPPs). They intend to strengthen projects appraisal to ensure effective screening of projects. My authorities have established a new Institute for Public Enterprises in order to address accountability and transparency requirements for public enterprises. Furthermore, the reconstitution of the BNA Audit Board will allow the issuance of semi-annual reports in compliance with its reserves investment guidelines. In order to diversify the economy beyond the oil sector and improve the business climate, my authorities' remain committed to implement reforms in key deficient areas including contract enforcement, transferring and registering property, and addressing weaknesses in the judicial system.

\section{Transparency and good governance}

My Angolan authorities are aware that accountability of public entities is crucial and in this regard, audited reports will continue to be published on regular basis for the main public 
companies such as Sonangol, Angola Telecom, Endiama (Diamond company), CFA (Angola railways) and EPAL (Luanda water supply company). By using external auditors, the Angolan authorities are demonstrating their commitment to good governance and transparency and thus convey a strong message to investors that the country stands ready to promote and support foreign investments and international cooperation.

\section{Conclusion}

Angola faces a period of recovery and stabilization. Under the SBA, fiscal and monetary policies as well as structural policies are steadily improving. My authorities consider the relationship with the International Monetary Fund fundamental for their development agenda and remain committed to cooperate with the Fund to realize their development objectives. 